NBER WORKING PAPER SERIES

\title{
WHAT DO UNIONS DO ... TO VOTING?
}

\author{
Richard B. Freeman \\ Working Paper 9992 \\ http://www.nber.org/papers/w9992 \\ NATIONAL BUREAU OF ECONOMIC RESEARCH \\ 1050 Massachusetts Avenue \\ Cambridge, MA 02138 \\ September 2003
}

I have benefitted from discussion with Ruy Teixeira, Joel Rogers, and participants at the Harvard University CAPs seminar and at Cornell University. Alida Castillo-Freeman analyzed an extraordinary number of data files from different surveys. The views expressed herein are those of the authors and are not necessarily those of the National Bureau of Economic Research.

(C)2003 by Richard B. Freeman. All rights reserved. Short sections of text, not to exceed two paragraphs, may be quoted without explicit permission provided that full credit, including (C) notice, is given to the source. 
What Do Unions Do ... to Voting?

Richard B. Freeman

NBER Working Paper No. 9992

September 2003

JEL No. J0, J5

\begin{abstract}
This paper uses data from four different data sets to examine the union impact on the turnout of members and their support for union-preferred candidates. It rejects the claim that the union share of the electorate rose massively in the 1990s. It finds that union members are about 12 percentage points more likely to vote than non-union members and nonunion persons in union households are modestly more likely to vote than persons in nonunion households, but shows that most of the higher rate of turnout of unionists is due to socioeconomic factors that differentiate union members from others. With respect to voting preferences, union members are more likely to vote for a Democrat for the House or Presidency than demographically comparable nonunion voters, largely because union members have attitudes and voting inclinations favorable to the Democrats and to liberalism prior to a given campaign. Finally, the study identifies a sizable group of nonunion persons with prounion attitudes that unions could potentially influence to maintain the union impact on elections even with declines in union density.
\end{abstract}

Richard B. Freeman

NBER

1050 Massachusetts Avenue

Cambridge, MA 02135

and Harvard University

freeman@nber.org 
American trade unions spend considerable resources on political activity. As union density has fallen, unions have increased their effort to mobilize union voters. In the 2000 Presidential election, AFL-CIO unions made 8 million phone calls to members, sent out 12 million pieces of mail, distributed 14 million leaflets at union workplaces once a week from September to Election day and spent more than $\$ 43$ million to help win a popular vote victory for the Democratic presidential candidate. ${ }^{1}$ In 2001, faced with declining resources due to falling membership and the Carpenters' Union withdrawal from the AFL-CIO, the General Board of the federation voted to increase its levy on unions to fund political activity through 2005 . The AFLCIO's Political Committee sought to elect 5,000 union members to public office - Target 5000. ${ }^{2}$

To what extent do union members turn out on election day more than non-union members? How much, if at all, do unions influence their members to vote for union-preferred candidates? In the face of declining density, can unions maintain their political influence?

Despite the importance that unions attach to political activity and the potential effect this activity has on election results, research on what unions do to voting is limited. Studies of union activity by economists focus on wages and other labor market outcomes. ${ }^{3}$ Studies of turnout and voting by political scientists focus on socio-economic determinants of voting but rarely examine

1 AFL-CIO power point presentations. Tracy Chang (2001) "The Labour Vote in US National Elections, 1948-2000, The Political Quarterly, 72 no 3, p 375. In1999-2000 unions gave 22.5 million dollars in soft money contributions to the Democratic National Committee, Democratic Senatorial Campaign Committee, and Congressional Campaign Committee.

${ }^{2}$ http://www.aflcio.org/issuespolitics/politics/fs_0202.cfm

${ }^{3}$ Freeman and Medoff (1984) have a chapter on unions in politics. Juravich and Shergold (1988) studied the impact of unions on the voting using a small sample of Pennsylvania union members. Masters and Delaney(1987) review studies of union political activities. Delaney and co-authors (1999) argue that unions have invested increasing resources in political action to defeat laws designed to weaken unions 
the impact of union activity on voting. ${ }^{4}$ The few social science studies that focus on unionization and voting have not pinned down the union impact on turnout and voting preferences. ${ }^{5}$

Absent extensive academic research, discussions of how unions affect turnout and voting are dominated by practitioner analyses of exit polls. Tabulations of Voter News Service (VNS) polls underlie claims that unions had a huge and increasing impact on elections in the 1990s. The most widely cited statistic is that the share of voters from union households rose from $19 \%$ in 1992 to $26 \%$, despite drops in union density. ${ }^{6}$ Exit polls indicate that in the 2000 Presidential election Vice President Gore obtained $63 \%$ of the union vote, and that heavy union campaigning gave him victory in several swing states -- Michigan, Pennsylvania, Wisconsin, and Iowa. Both Republican and Democratic politicians attributed Gore's near win to organized labor. ${ }^{7}$

${ }^{4}$ Shlotzman, Brady, and Verba (1995) show that union members are more exposed to political discussion and activity and to developing civic skills than others (table 13.4). Chang (2003) examines get out the vote campaigns of 140 local unions in the South. Delaney, Fiorito, and Masters (1988) examine the determinants of union political action committee and lobbying expenditures. Verba, Nie and Kim (1978) provide evidence that class-based institutions such as unions also mobilize citizens. Radcliff and Davis (2000) attribute some of the low level of turnout and high class bias of voting in the US to the weakness of US trade unions.

${ }^{5}$ Examining the turnout of union members and their response to COPE endorsements in the 1978 election John Delaney and co-authors $(1988,1990)$ concluded that union members turned out more than non-members but that persons in union households did not; Radcliff's (2002) examination of electoral participation of persons in union households in the NES from 1952 to 1992 found a union effect that differed substantially between models.

${ }^{6}$ Various AFL-CIO representatives have presented these data. See Steve Rosenthal, power point presentation "How Can Labor Impact the Current Political Debate?" Harvard Trade Union Program, January 14, 2003. This claim is repeated often in newspaper stories: "labor's relative strength at the ballot box continues to grow in the face of overall declines in voter turnout. The share of union household voters has grown from 19 percent in 1992 to 23 percent in 1996 to 26 percent in 2000." Leigh Strope, "Gebhardt Adds to Growing Union Support" Associated Press, August 5 http://www.thestate.com/mld/thestate/news/politics/6459981.htm

7 Senator Joe Biden "If Al Gore wins, he'll win for one simple reason: organized labor" Associated Press, 11/4/00. William Schneider "If Gore becomes President, he'll owe organized 
This study examines the VNS exit poll data that underlie claims of increased union political effectiveness in the 1990s and data on unionism and voting from the November Current Population Survey (CPS) supplements on voting, National Election Studies (NES) surveys, and the General Social Survey (GSS). Investigating the relation between unionism and voting in these four sources of data provides a more complete and different picture of what unions do to voting than that given in previous studies.

There are five substantive findings:

1. Exit poll data give a misleading picture of the trend in the union share of the electorate, and thus of the extent to which unions offset loss of density through get-out-the-vote campaigns.

2. Current Population Survey voting supplements understate the union share of voters by excluding retirees and other non employed persons with union affiliation from their measure of union members. Counting non employed persons who claim union membership as union voters, the union share of voters is about $50 \%$ higher than the union share of workers.

2. Union members are 10-13 percentage points more likely to vote than non-union members, but the union voting premium - defined as the difference in turnout between members and non-members with comparable characteristics - is much smaller: about 4 percentage points.

4. Union members are 12 to 13 percentage points more likely to vote for a Democrat than are demographically comparable nonunion voters, but about half of this difference is due to union members holding favorable attitudes toward liberalism and the Democratic party. All but 2-3 percentage points of the difference arises prior to a given campaign.

labor big time" CNN, 11//00. "We know the unions to be our chief adversary in this election" Executive Director, Pennsylvania Republican Party, 11/00. All from AFL-CIO presentation 
5. Three to four times more non-union than union voters hold very positive views of trade unions, suggesting that in an era of declining density a successful union political strategy depends on union ability to reach and influence these non-members.

\section{The Union Share of the Electorate: Exit Polls vs Surveys}

The political world uses exit polls to judge the importance of unions in the electoral process. Exit polls ask voters who leave the polling place to fill out a short questionnaire on how they voted and on their demographic and economic characteristics. Prior to 1992 different news services had their own exit polls. From 1992 to 2000 the TV networks and newspapers combined resources to create the Voting News Service to conduct exit polls in national elections.

Exit polls influence political thinking. In the 1990s some analysts argued that the Democratic Party should seek upper income groups - soccer moms in suburbia rather than blue collar workers, in part because exit polls show that college graduates make up a large proportion of voters. ${ }^{8}$ As noted, claims that union political activity became more effective in the 1990s rests in part on exit poll data that show a rising share of voters from union households.

Figure 1 displays the VNS estimate of the proportion of voters from union households from 1992 to 2000 and the proportion of voters who were union members in 2000. Until 2000, exit polls did not ask voters whether they were union members. Instead, it asked if they had union members in their household. For this reason trend studies of the union share of voters focus on the proportion of voters in union households rather than the proportion of voters who are union members. The reported exit poll trend is striking: a seven percentage point increase in the proportion of voters from union households between 1992 and 2000 driven by an increase of 4.8 million voters in union household compared to a decrease of 15.5 million voters from

\footnotetext{
${ }^{8}$ For a critique see Teixera (1992), Rogers and Teixera (2001)
} 
nonunion households. This, despite a drop in union density of 2.6 percentage points over the same period. With numbers like these it is no wonder that union leaders saw the political process as an efficacious way to exercise influence on behalf of workers.

But the VNS picture of the union voting population is inconsistent with estimates of union membership at workplaces. In 2000 the voting age population consisted of 206 million adults. Unions had 16.3 million members, 13 million in the AFL-CIO, 2.6 million in the NEA, 0.4 million in the Carpenters union, and the remainder in various independent unions. Thus, union members made up $7.9 \%$ of the voting age population. Census data indicate that households average 1.9 adults, so that approximately $15 \%$ of all persons of voting age were in union households. ${ }^{9}$ Higher turnout by union members than non-members could readily raise the proportion of voters in union households $2-3$ percentage points above $15 \%$ but not to the $26 \%$ of voters shown in figure $1 .^{10}$ To increase the proportion of voters in union households by the 7 percentage points shown in the figure would require union turnout to rise by 30 percentage points relative to nonunion turnout. This is a near arithmetic impossibility ${ }^{11}$ and a near political

9 US Census Bureau, Statistical Abstract of the United States gives 202.6. million persons of voting age and 104.7 million households in 2000 (table 54), which gives 1.94 adults per household in that year. The size of households has been falling.

${ }^{10}$ If half of the nonunion adult population voted, and the turnout of union members exceeded that of nonunion adults by 10 percentage points, the union share of voters would be $17.5 \%$; if turnout among union members was 20 percentage points above that of nonunion adults, the union share of voters would be $19.8 \%$ — far below the $26 \%$ reported by VNS.

11 The following calculations show this. For 1992 the VNS estimates that 21.6 million voters were in union households; CPS data show that approximately 31.2 million persons were in households with union members in 1992. This implies a turnout in union households of 69\%. For 2000 the VNS estimates that 26.3 million voters were in union households while CPS data show that about 31 million persons were in households with union members, giving a turnout in union households of $85 \%$. By contrast, the VNS estimates that 92.2 million voters were in nonunion households in 1992; CPS data suggest that approximately 162 million persons were in nonunion households in 1992 , giving a turnout rate of 58\%. In 2000 the VNS estimates that 
impossibility since it implies that Clinton won the 1992 election with low union voting.

If the VNS trend data are inaccurate, where can we get a better picture of the union share of the electorate? And what exactly is wrong with the VNS numbers?

\section{Alternative Sources: CPS , NES, and GSS}

Three nationally representative surveys provide information on voting by union status: the CPS November voting supplements; the National Election Study (NES) conducted by the University of Michigan; and General Social Survey (GSS) conducted by the National Opinion Research Center of the University of Chicago.

The CPS asks all adults or all adults eligible to vote about their registration and voting in November of each national election year. The survey also asks employed respondents in the outgoing rotation group about union membership and collective bargaining coverage at their workplace. Combining respondents who report their union status and voting behavior gives a sample of roughly 12,000 persons per year - the largest survey based sample with information on unionism and voting. While the CPS does not ask if other members of the household are union, the CPS sample contains a household identifier from which I construct households and thus determine which households have union members. ${ }^{12}$

The NES provides information on whether a voter was in a union household from 1948 to

76.8 million persons from nonunion households voted; CPS data suggest that approximately 176 million persons were in nonunion households, giving a turnout rate of $44 \%$. Thus, the figure 1 data imply a 16 point increase in turnout from union households and a 14 point fall in turnout in nonunion households! One problem is that the VNS shows a 10.7 million fall in voters between 1992 and 2000, whereas administrative data show an increase of 1.2 million. (See www.fec.gov/votregis/turn/natto.htm and www.fec.gov/pages/2000turnout/reg\&to00.htm.)

${ }^{12}$ It is possible to obtain data on the union status of persons not in the outgoing rotation group in the November samples by matching them to union data for the months when they are in the outgoing rotation group. Since the November sample has approximately 12,000 persons in the outgoing rotation group, there is no need to expand the sample through such matching. 
2000 and whether the voter was a union member from 1996 to 2000. It is the most detailed survey on voting behavior, asking about political activity and attitudes through both a preelection survey and post-election survey. The NES asks about the party/candidate for whom the respondent voted. It validated self-reported voting in several elections from 1964 to 1990 by sending field interviewers to local election offices to look at the office's record of participation for NES respondents. This is important given that more individuals report having voted than actually do so. But the NES sample is much smaller than the CPS sample -- around 1700 respondents per election. ${ }^{13}$

The GSS contains information on the union membership of the respondent and their spouse and whether they voted in elections from 1972 to 1998. It also contains questions on the persons' attitudes toward political and economic issues and whether they engage in other political activities, such as contributing to a political party or going to rallies.

In this study I concentrate on the CPS files because the CPS has the largest number of respondents, low non response rates, and a smaller reporting bias in voting than the NES $;{ }^{14}$ and because the small sample sizes of the NES and GSS surveys gives them few union respondents from which to examine the voting behavior of union members. ${ }^{15}$ Still, the NES and GSS are helpful in assessing divergences between the VNS and CPS and the NES is critical for estimating how union status affects party/candidate preference, on which the CPS is silent.

${ }^{13} \mathrm{See} h \mathrm{htp}: / /$ www.umich.edu/ nes/studyres/nes 48 00/nes 48 00.htm for the number of persons in each years' election sample.

${ }^{14}$ CPS response rates average around 93\%. The National Center for Educational Statistics, Supplemental notes 2 shows the low over-reporting bias in the CPS http://nces.ed.gov/programs/coe/2003/notes/n02.asp

${ }^{15}$ There were 134 persons who reported union membership on the 2000 NES and 167 persons who reported union membership on the 1996 GES. 
Table 1 records the union share of voters in the CPS, NES, and GSS surveys from 1990 to 2000 and compares that information with VNS exit poll data. The CPS asks two questions about union status: whether the person is a union member and, for non members, whether their workplace is covered by a collective bargaining contract. Since a union affects all workers at an organized work site and the union wage literature focuses on having a collective contract, I measure unionism as the sum of these responses. ${ }^{16}$ The NES and GSS questions relate to union membership only. The first four columns of table 1 record the percentage of voters who say they are union members/covered by a union contract. The next four columns record the percentage of voters from a household with at least one union member. Because the CPS scrambled the household identification variable in the November 1994 survey, I cannot estimate union household voting in that year.

There are striking differences between the VNS and the other surveys in the level and trend in the union share of voters. In 2000 the CPS and NES show similar proportions of voters in unions, (11\% (CPS); 10\% (NES)) and in union households (17\% (NES); 19\% (CPS)). By contrast, the VNS reports a union share of voters of $16 \%$ and a share of voters from union households of 26\%. The GSS estimated share of union members among voters in 1992 and 1996 modestly exceeds the CPS estimates, but the GSS estimated share of voters from union households are in the same range as the NES and CPS estimates in those years. With regard to trend, the CPS and NES show slight drops in the union household share of voters while the GSS shows stability in the union share. This contrasts to the 1992-2000 increase in the union household share of voters in the VNS.

${ }^{16}$ The number of persons who report that they have a collective bargaining contract but are not members is less than $10 \%$. The CPS does not ask whether union members have a collective contract. 


\section{Why does the VNS give a rising trend?}

The reason the VNS gives a rising trend in the union household share of voters whereas the other surveys show stable or falling density can be readily determined. The reason is that the VNS changed its questions about union status over time in a way that biases the trend upward. Panel A of table 2 records the VNS questions about union status in 2000, 1996, and 1992. In 2000 the VNS asked if the respondent or someone else in their household was in a union and probed whether the individual, someone else, or both were in the union. In 1996 the question was: “do you or does someone in your household belong to a labor union?" and had places for the respondent to mark yes or no. The probes in 2000 arguably led to more people reporting union members in their household than in 1996, but the big change in questions occurred between 1992 and 1996.

In 1992 the VNS did not ask a regular question about union status. Instead, it asked respondents to check yes if they were in a union household as part of a "Grabbag" of 9 items questions about whether the person was a born-again Christian, whether they once thought they would vote for Ross Perot, were a first-time voter, and so on. The grabbag item was the last question on the second page of the questionnaire, which some persons did not read or read but did not answer. This design necessarily underestimates the union share of persons in that year's poll. The VNS warns: "Exit poll users are cautioned against comparing estimates from the Grabbag with those from full questions because the Grabbag significantly underestimates the population values ${ }^{17}$ Failure to heed this warning produced the putative jump in the union share of voters from 1992 to 1996 and 2000.

17 Voter News Service General Election Exit Polls, ICPSR 2780, 1988 VNS Exit Poll Methodology, p 8, 
Panel B of table 2 uses information from earlier exit polls to show that the change in question design can indeed account for the reported trend. In $1988 \mathrm{CBS}$ and $\mathrm{ABC}$ ran their own exit polls. CBS used a question comparable to the 1996 VNS question: "Are you or is any person living in your household a member of a labor union?" and obtained a positive response from $26.6 \%$ of voters. $\mathrm{ABC}$ listed a set of 14 items under the question "do any of the following apply to you?" including being a member of a union household. Barely 10 percent of respondents checked this item. Thus within the same year the two questions elicited responses that varied by 17 percentage points. Going further, in $1984 \mathrm{ABC}$ asked a question "is anyone in the household in the union?" as a separate item and obtained a $26.9 \%$ response. The responses to different forms of the union question validates the VNS warning that responses from the grabbag design cannot be compared to responses from single question items.

On the basis of the CPS trend data in table 1, I conclude that the share of voters in unions fell by about 1 percentage point and the share of voters in union households fell by about 2 percentage points from 1990 to 2000. The VNS-based estimated increase in the union share is erroneous.

\section{What is the correct union share of voters?}

So much for the trend. Which of the numbers in table 1 provide the best estimate of the the union proportion of voters in 2000? Why does the VNS record higher shares of union voters than the CPS and other surveys even though union status questions in 2000 are quite similar?

One reason the VNS reports a higher union percentage than the CPS is that the VNS asks the union status of persons regardless of their employment status, whereas the CPS asks union membership only for wage and salary employees. By asking non employed as well as employed persons to declare their union status, the VNS necessarily reports a larger union share of the voting population than the CPS. But the NES and GSS also ask all respondents about their union 
status and report union shares of voters closer to the CPS estimates than to the VNS estimates.

To get a better handle on the differences in the union share of voters among surveys, I computed the union share of voters by employment status and age. Since the CPS asks union status only of employed persons, the comparable figures from the other surveys relate to employed persons. If many non employed persons call themselves union members because they are retirees affiliated with a union, the VNS, NES, and GSS should show a high union share of older non employed voters.

Table 3 gives the share of voters who report themselves union members by employment status and age in the CPS, VNS, and NES in 2000 and in the GSS for 1996. In the CPS, NES, and GSS, employment is defined by a standard labor force activity question; whereas the VNS asks whether or not the person works full-time. Although this excludes part-time workers, the VNS sample contains a higher proportion of employed persons than the CPS sample of voters (presumably due to response bias in exit polls, where employed educated persons are more likely to respond). Still, among employed persons, the union share of voters in the VNS is similar to that in the CPS. The outlier in terms of the voting of employed persons in 2000 is the NES, which shows a relatively low union share of employed voters. The similarity between the VNS and CPS figures in the union share of employed voters supports the claim that the union share of voters is higher in the VNS because the VNS includes non employed persons as union voters. Among non employed persons, the VNS and 1966 GSS estimates of the union share of voters give similar estimates, with the NES again recording the lowest union share.

So the question becomes,"should we regard non employed voters who declare themselves to be union members on the VNS and other surveys as genuine unionists for calculating the union share of the electorate, or should we view the large number of non employed members as 
largely measurement error?" If the estimated number of non employed union members is valid, the VNS gives a better measure of the union share of voters (though not of the trend in the share) than the CPS. If the estimated number of non employed union members is due largely to measurement error, the CPS gives a better measure of the union share of voters than the VNS.

As noted, some non employed persons reporting themselves as union members are likely to be retirees who retain union membership or otherwise identify with the union that represented them when they were employed. In this case, we would expect that the VNS, NES, and GSS to show a larger union share of voters among older non employed persons than among younger non employed persons. Table 3 does not support this expectation. The union shares of voters among non employed persons are not markedly different for persons aged 60 or older than for younger persons. Still, because older persons are more likely to be non employed and are more likely to vote than younger persons, the older persons make up a large proportion of non employed union voters. In the VNS $41.3 \%$ of non employed union voters were aged 60 or more; in the NES $41.7 \%$ of non employed union voters were aged 60 or more; in the GSS $75 \%$ of non employed union voters were aged 60 or more. In addition, on the NES $50 \%$ of non employed union voters said that they were retired, while on the GSS $69.4 \%$ of non employed union voters said that they were retired. ${ }^{18}$ Thus, a sizeable proportion of non employed persons who say they are union members are retirees likely to be connected to unions in some fashion.

Union estimates of the number of retirees affiliated with them provide an independent check on the importance of this group in the union share of voters. The AFL-CIO claims that 2.5 million retirees are part of its Alliance for Retired Americans - a group set up by the unions to

\footnotetext{
${ }^{18}$ These are all based on small samples, as pointed out in footnote 15.
} 
provide a voice for retired workers, that includes retirees from all federation unions. ${ }^{19}$ The United Automobile Workers reports approximately 710,000 active members and over 500,000 retired members in the United States, Canada and Puerto Rico. ${ }^{20}$ Outside the Federation, the National Education Association reports over 205,000 members in its NEA-Retired affiliate. ${ }^{21}$ Other independent unions presumably also have retirees who maintain a union link. If the CPS had asked these persons their union status and they had declared themselves as "union", the union proportion of adults of voting age would be $16 \%$ higher than reported on the CPS ${ }^{22}$. If, moreover, the turnout of these persons exceeded that of nonunion persons by an amount similar to that found among the employed on the CPS, the union share of voters would be $13 \%$ rather than the $11 \%$ given in the CPS column in table 1 . This two percentage point difference is roughly one third of the difference between the VNS and CPS estimates of the union members' share of voters in table 1.

The VNS and CPS differ in other ways, however, that suggest that, retirees aside, CPSbased estimates of union voters may be more accurate than VNS-based estimates. The response rate of the VNS in 2000 was just $51 \%$ - a decline from $60 \%$ in 1992 - whereas the CPS response rate has been fairly constant at about $93 \%$. The VNS reports a higher share of voters with

${ }^{19}$ See http://www.retiredamericans.org/ But the AFL-CIO automatically enrolls retired members of participating unions and members of its predecessor organization the National Council of Senior Citizens into the Alliance for Retired Americans without charging dues. Many retirees may not know they are affiliated with the union group or may reject such an affiliation.

${ }^{20} \mathrm{http}: / /$ www.uaw.org/about/uawmembership.html

${ }^{21} \mathrm{http} / / / \mathrm{www}$. nea.org/retired/about/history.html

${ }^{22}$ This statistic is obtained by dividing the 2.7 million retirees reported by the AFL-CIO and NEA by the 15.6 million members in the two groups, giving a figure of $16 \%$ and assuming a similar percentage for 
college degrees and a smaller share of voters with high school or less education than the CPS (Texeira, 2000). ${ }^{23}$ In addition, whereas the VNS and CPS surveys report similar union shares of voters among those with 4 or $5+$ years of college, the VNS reports a much larger union share of voters among less educated workers than the CPS. The implication is that the VNS under represents less educated nonunion voters, and thus may overestimate the union share of voters.

\section{Voting behavior to judge union responses}

Another way to assess the validity of the union status of non employed persons whom the VNS counts as union is to examine how these "union members" vote. If non employed union members vote in the same manner as employed union members, counting them as union voters would seem reasonable. By contrast, if non employed union members vote in the same manner as nonunion voters, counting them as union voters would seem to be erroneous. Formally, assume that non employed union respondents are a mixture of "real" unionists and persons given that label due to measurement errors. Let " be the share who are real unionists, $\mathrm{P}$ be the proportion of real union (employed) persons who support union favored candidates, and Q be the proportion of nonunion non employed persons who support union favored candidates. Then "P $+(1-") \mathrm{Q}$ would be the observed proportion of non employed persons claiming to be union members who support union favored candidates. In 2000 unions supported the Democratic candidate for President and Democratic candidates in most House races, so I use the proportion of voters who favored the Democrats to measure Q.

Figure 3 displays the relevant conditional probabilities in the 2000 VNS. It shows the

${ }^{23}$ In 2000 I find the following proportions of voters in a union by education groups:

CPS college graduates, 5+ college grads, 4 college 1-3 hsgrads less than hs

VNS $10.7 \%$ 20.9 30.5 28.7 9.3 23.9 32.4 20.9 
proportion of employed and non employed voters by union status who supported the Democrats in the 2000 Presidential and Congressional elections. The non employed persons who claimed union status voted Democratic in proportions much closer to employed unionists than to nonunion voters. For the Presidential election, the estimated " is 0.82 ; for the House election, it is 0.72 . To be conservative I will count $75 \%$ of the reported union non employed persons on the VNS as being valid union responses in assessing union proportion of non employed voters.

Given an estimate of the proportion of non employed voters who are union, I form a weighted average of the union share of employed voters and of the union share of non employed voters to obtain the union share of all voters. In $200067 \%$ of all voters were employed and 33\% were non employed. ${ }^{24}$ Given its size and representativeness, the CPS offers the best estimate of the union share of voters among the employed: $18 \%$ in 2000 . For the union share of non employed voters, I average the VNS, NES, and GSS's (1996) estimated union shares of note employed voters to obtain $9.2 \%$ and discount this average by $25 \%$. This gives an estimate of the union share of non employed voters of $6.9 \%$ and an estimate of the union share of all voters of 14.4\%. This statistic is closer to the VNS estimate than to the CPS estimate in table 1. To transform this into an estimate of the proportion of voters in union households, I multiply it by the ratio of the union household share of voters to the union share of voters in the 2000 CPS from table 1 . This yields an estimate that $25 \%$ of voters come from households with a union member - again closer to the VNS statistic than to the CPS statistic. ${ }^{25}$

\section{The Effect of Union Membership on Turnout}

The union share of the electorate depends on the union share of the voting age

\footnotetext{
${ }^{24}$ See US Statistical Abstract 2001, table 401

${ }^{25}$ Here I take the CPS estimate that each family has about 1.9 adults.
} 
population, and on the turnout of union members and their families. In this section I use the CPS, NES, and GSS to compare the turnout of persons associated with unions to the turnout of persons with no union connection. I estimate two statistics: the union voting gap, defined as the mean difference between the proportion of union members (or members of union households) who vote and the proportion of nonunion members who vote; and the union voting premium, defined as the difference in voting rates among persons with and without union attachment who have observationally similar characteristics. The union voting gap is analogous to the mean difference in wages between union and nonunion workers. Given the union share of the voting age population, it determines the share of voters who are union. The union voting premium provides an estimate of the causal impact of unionization on turnout analogous to labor economists' estimates of the union wage effect.

\section{the union voting gap}

To assess the union voting gap, I tabulated the proportion of persons who vote by union status in the CPS, NES, and GSS surveys. Because some survey respondents report that they voted in an election when they did not, the raw figures yield an upwardly biased estimate of the turnout of both union and nonunion persons. To see if the bias is correlated with union status, I examined the level of misreporting of voting by union status in NES surveys that included a validation check based on administrative records. These calculations show that a similar proportion of reported votes were valid between union and nonunion members (Appendix table A). On average the NES validated the votes of $84 \%$ of union members who said they had voted and validated the votes of $82 \%$ of nonunion members who said they had voted. Thus, on this survey at least, union members and nonmembers exaggerated their participation at the ballot box similarly, in a way that can be rectified by multiplying the reported turnouts by the estimated 
rates of over reporting.

Table 4 records the proportion of persons who vote in the CPS by their employment status, their union status, and the union status of their household. Because the CPS scrambled household IDs in the November 1994 survey, I could not construct households in that year, so there are no 1994 union household figures. The columns headed "Employed persons" record the voting rates of four groups: union members, nonunion employed persons, and nonunion employed persons in union households and nonunion employed persons in nonunion households. The differences in voting rates between union members and all employed persons average 10.0 points in presidential year elections and 13.0 points in midyear elections (bottom lines, column 1 - column 2). In addition, employed nonunion persons in union households have a 4 point higher rate of voting than employed nonunion persons in nonunion households (column 3-column 4). Within union households, members have a 7 to 9 percentage point voting advantage over employed non-members (column 1- column 3).

The columns headed "non employed persons" contrast the voting rates of non employed persons in union households with the voting rates of non employed persons in nonunion households. Here, the story is quite different. Non employed persons in union households vote less frequently than non employed persons in nonunion households. The union/nonunion difference is -1.3 points in presidential elections and -7.2 points in non-presidential elections.

One possible explanation for the differential union household effect on the voting of non-members by their employment status is that the workplace and employment issues that unions stress resonate more with the employed than with the non employed. One possible explanation for the negative effect of unionism on the voting of non employed members is that the non employed in nonunion households tend to be older than the non employed in union 
households.

Ensuing regression analyses will examine this possibility.

Finally, the columns headed "all" in table 4 give the voting rates of all persons in households with union members and the voting rates of all persons in households with no union members. Persons in union households have 5 to 6 point voting advantage over persons in nonunion households.

Figure 2A shows the union voting gap between persons in union households and those in nonunion households on the NES for each election from 1948 to 2000 . In all but two elections persons from union households had a higher voting rate than persons from nonunion households. Over time the union voting advantage in the NES rises from 3-4 percentage points to 10 or so percentage points in the 1990s, which is larger than the CPS union household advantage in the 1990s. Figure 2B displays the percent of persons in union households and the percent of persons in nonunion households who voted in presidential elections in the GSS surveys from 1968 to 1998. Again, there is a union turnout gap, which rises to 10 or so points in the 1990 s.

On the basis of these data, I conclude that union members and persons in union households are more likely to vote than non-members, with a 10 percentage point gap for members and a 5-6 percentage point gap for households in the CPS and larger differentials for households in the other surveys in the 1990s.

\section{the union voting premium}

To what extent, if at all, do to the mean union/nonunion differences in voting rates reflect differences in the characteristics of union/nonunion associated persons as opposed to the impact of unionism per se or union mobilization campaigns on their voting behavior?

An ideal way to answer this question would be to compare the voting behavior of the 
same person from one election to another as they moved from a union to a nonunion job or conversely. ${ }^{26}$ An alternative research strategy would be to relate union members voting behavior to differences in unions allotting more/less resources to mobilizing voters among elections. ${ }^{27}$

The CPS data do not follow persons from one election to the next, and there are no readily available data on the allocation of union resources across states, so that the best I can do in this study is to estimate the extent to which the union voting gaps shown in table 4 are attributable to differences in measurable socioeconomic characteristics between union members and nonmembers. Accordingly, I estimate a linear probability model that relates a dichotomous VOTE variable $(1=$ voted; $0=$ did not vote $)$ to socioeconomic covariates and dummy variables for the union status of a person or their household.

Because the CPS differentiates persons by their employment status, union status, residence in a household with another adult, and by the employment and union status of that other adult, variations along these dimensions create 9 non-overlapping groups of union and nonunion persons ${ }^{28}$ from which one can make various union/nonunion comparisons Rather than presenting a full set of group differences, I focus on three main comparisons.

${ }^{26}$ This comparison has complexities. If unions induced someone to vote, persistence of voting would bias downward the estimates of the union impact on voting behavior when a person went from union to non-union status. In this case, a better test of the union effect would be to compare the change in voting among persons who switched from a nonunion job to a union job.

${ }^{27}$ This also has complexities, since the decision to devote effort to one election rather than another will be partially influenced by union leaders' belief in how the elections might proceed and in the effectiveness of a union mobilization campaign.

${ }^{28}$ There are five nonunion groups: nonunion employed person living alone, nonunion non employed person living alone; for persons living with another person: two nonunion employed persons; one employed person and one non employed person, and two non employed persons. There are four union groups: union persons living alone; two employed union persons, one union and one nonunion employed; and one union and one non employed person. 
First, I examine differences in voting between employed union members and employed non-members, regardless of whether they are in a union household or not:

(1) $\operatorname{VOTEi}=a+b$ UNIONi $+\mathrm{Zi}+$ ui, where UNION measures union membership of employed persons; $\mathrm{Zi}$ is a set of dummy variables for socioeconomic covariates, ui is residual. When a particular covariate is missing, I include a dummy variable that flags that the data are missing. This preserves the sample size by making the missing another category without distorting the comparisons.

Table 5 summarizes estimates of model (1) in terms of the coefficients and standard errors on the dummy variable for unionization. Each coefficient comes from a separate regression with the specified covariates in the specified years. The first six lines refer to separate elections. The next line summarizes the pattern over the six elections by giving the estimate coefficient on unionism from a single regression using a pooled sample of the CPS November files (with inclusion of dummy variables for the year of the election as well).

Column (1) gives the estimated coefficient on union membership from a univariate regression of VOTE on a union dummy variable, and thus estimates the raw difference in voting between union members and employed nonmembers. The differences in this column vary modestly from those in table 4 because the regressions treat each observation equally whereas the means in table 4 weighted persons by the CPS sample weight. Column (2) gives the mean difference between employed union members and employed non-members conditional on dummy variables for the demographic characteristics of the individual: age, education, gender, region, and race, as specified in the table note. Adding these covariates reduces the estimated voting difference by 4 percentage points in the pooled regression, with moderate variation across elections. The third column gives the union/nonunion difference from regressions that add 
dummy variables for occupation and class of employment to the covariates, as specified in the table note. This reduces the union/nonunion difference by 2 percentage points on average. The union coefficient of 0.06 in the pooled sample is just half of the initial 12 point union/ nonunion member difference in voting. The fourth column gives the union coefficient from regressions that include dummy variables for family income. This lowers the union coefficient by another 2 percentage points in the pooled sample. Comparing the 0.04 coefficient in column (4) with the 0.12 coefficient in column (1) for the pooled sample, we see that the regression accounts for 2/3rds of the union voting gap.

My second comparison deletes from the sample employed nonunion persons in union households, on the assumption that unions affect the voting behavior of nonunion members in union households as well as affecting the voting behavior of members. The line listed "employed union and employed nonunion in nonunion household" records the coefficients and standard errors from regressions limited to those groups for the pooled 1990-2000 sample. If unions raise the probability of voting for nonunion employed persons in union households, the the estimated coefficients on unionism in these lines should be larger than those in the preceding line and give a more valid estimate of the union impact on voting. In fact, the coefficients on unionism in these regressions are similar to those from the sample that includes all employed nonunion members: there simply are not enough employed nonmembers in union households for the change in sample to have much impact on the regressions.

The last line in table 5 limits the sample comparisons even further. It presents regression coefficients for the union impact on voting for persons in 2 adult households only. This enables me to assess the possibility that characteristics of another adult in a household as well as the person's own characteristics affects their voting. It is possible that some of the estimated union 
effect on voting could be due to the characteristics of other members of a union household rather than with union status. Union members might, for example, have older highly educated spouses than nonmembers, which would increase their likelihood of voting independently of unionism per se. To the extent that union members have other household members with characteristics that lead persons to vote, the regressions that exclude the characteristics of other household members could overstate the impact of unionism on turnout. Accordingly, the regressions in line 4 limit analysis to households with two adults where at most one is a union member and adds dummy variables for the age, education, occupation, and class of worker of the other adult in the household to equation (1). ${ }^{29}$ The column 5 regression shows that inclusion of the characteristics of the other adult resident in the household does not change the coefficient on union membership from that in column 4 when those characteristics are not included. The estimated final union effect in this line is 0.05 , which compares to an initial differential of 0.11 in this sample.

In sum, there is a union/nonunion voting premium among persons with observationally equivalent characteristics, including characteristics of the other adult in their household, of about 0.04 points, with some variation among elections and samples. Much of the union/ nonunion voting gap is due to the differential characteristics of union and nonunion workers.

\section{The effect of a union household on nonunion persons}

As noted, unions may affect the voting behavior of nonunion members of households with members. Indeed, an implicit assumption in analyses that focus on the share of voters from union households is that the voting behavior of non-union persons in union households differs from that of persons in nonunion households. To examine the impact of being in a union

${ }^{29}$ Since this analysis focuses on the characteristics of another person in the household but not on that persons voting behavior, it does not run into the Manski "reflection problem" that results from having the dependent variable on both sides of the equation. 
household on the voting behavior of nonunion members, I estimate the following equation:

(2) $\operatorname{VOTEi}=a+b \mathrm{UHi}+\mathrm{Zi}+$ ui, where UH is a dummy variable that measures whether the household has a union member.

For ease of presentation, I summarize in table 6 the results of estimating equation (2) for the pooled 1990-2000 sample (with 1994 excluded due to the Census's scrambling family IDs). Since I am concerned with the effects of a union person on nonunion members in a household, I limit the sample to nonunion persons living in households with more than one adult. Each of the coefficients in table 6 comes from a separate regression with the covariates as specified in the relevant column. Line 1 estimates the effect of being in a union household on all persons in households with more than one adult. The coefficient absent any covariates in 0.03 . This differential is one-quarter of the 0.12 differential between union members vs nonmembers in the comparable table 5 calculation (line 2, column 1, for pooled all employed sample). The estimated union effect in table 6 rises with the addition of demographic and job covariates (columns 2 and 3 ) but then falls back to 0.03 in column 4 with the addition of the dummy variables for household income. In column 5, I examine the possibility that the characteristics of union members of households rather than their union status underlies the higher voting rate of nonunion persons in union households, by adding dummy variables for the age, education, occupation, and class of worker of the other person in the household. This calculation compares the voting behavior of persons in union and nonunion households with otherwise observationally equivalent household members. The coefficient on union household member falls to 0.02 . This union impact is smaller than the union voting premium estimated for members in table 5 .

To examine whether the table 4 finding that being in a union household is associated with higher turnout of employed nonmembers but lower turnout of non employed non-members, I 
estimated equation (2) separately for nonunion persons who are employed and those who are non employed. Lines 2 and 3 of table 6 give the regression coefficients from these calculations. The coefficients on unionization in lines 2 and 3 of table 6 suggests that much of the differential voting behavior between employed and non employed nonunion members in union households is attributable to their differing characteristics. Column 1 estimates that unionism has a 0.07 impact on the voting of non-members among employed persons compared to a -0.02 impact on non employed members of the household. But addition of demographic covariates reduces this 9 percentage point gap in voting to just 2 percentage points, and the addition of other covariates keeps the estimate in the 1 to 2 percentage point range. In the calculation with all the covariates the difference between the estimated union coefficients for employed and non employed nonunion members is modest, about 1 percentage point. Thus these calculations show that unions do only marginally better mobilizing employed persons in union households than they do in mobilizing non employed persons to vote.

Finally, note that the comparison of employed nonunion persons in union households to employed nonunion persons in nonunion households in line 2 of table 6 uses the same nonunion household group as its base for estimating the union effect as did the calculations for the pooled sample that excluded employed nonunion persons in union households in line 2 of table 5 . The difference in the coefficients between these two lines give the union voting effect on union members and on employed nonmembers in households relative to the same nonunion employed group. The coefficient on union members is much larger than that for nonmembers in union households in the relevant column 1 regressions of tables 5 and 6 (a 5 percentage point gap $=$ $0.12-0.07)$, but the difference in coefficients decline rapidly with the addition of covariates to 0 percentage points in columns 3 and 4 between the two tables. The implication is that unions 
have as great an effect on the turnout of employed nonmembers in union households as on members.

In sum, the CPS data shows that among observationally equivalent persons, union members have a higher turnout than non-members, while nonunion persons in union households also have higher turnout than persons in nonunion households. Although the regression analyses cannot rule out the possibility that some unobserved fixed characteristic of union members or households underlies the differences, at the minimum they show that the union voting premium is much smaller than the raw union/nonunion difference in voting rates.

\section{The Effect of Unions on Party Voting Preferences}

If union members voted similarly to other voters in elections, their higher turnout would not influence election outcomes. Exit polls show, however, that union voters disproportionately support Democrats in national elections. In the Presidential election of 2000 union members voted $62 \%$ for Gore while non-members voted 52\% for Bush. In the 2000 New Hampshire Democratic primary, $60 \%$ of union household members voted for Gore while $51 \%$ of nonunion households voted for his rival, Bradley. Political analysts often cite statistics like these to show the influence unions have on the voting behavior of their members.

Simple comparisons of the voting choices of union members and nonmembers are, however, likely to overstate the extent to which unions affect the votes of their members. Such comparisons do not distinguish between preferences that union members have independent of union politicking. As democratic organizations, unions generally endorse candidates favored by a majority of members, so that even if unions did not influence how members voted, a majority of members would vote for union-endorsed candidates. To determine whether unions influence members' votes requires analysis of the voting behavior of union members on the margin 
between candidates or inclined toward union-opposed candidates compared to the voting behavior of otherwise comparable nonunion voters, and to the extent to which union members intending to vote for union favored candidates end up voting for them compared to otherwise comparable nonunion voters intending to vote for union favored candidates.

Perhaps the most striking example of union success in changing votes occurred in the 1998 California referendum over proposition 226, the so-called paycheck protection bill. This proposition required unions to obtain members' written permission before they could use dues money for political purposes and prohibited employers from making automatic deductions from paychecks for political contributions or expenditures without the workers' annual written permission. Claiming that unions in California spent approximately $\$ 81$ million of their dues for political purposes over a typical two-year election cycle, conservatives introduced the referendum to reduce union political spending and influence. Initially, most voters supported the proposition. A January 1998 California Field poll found that 71 percent of the general public and two-thirds of union households favored the proposition..$^{30}$ But the AFL-CIO and California unions undertook a massive campaign to convince voters that the initiative would unbalance politics by reducing union spending while allowing corporate funding of candidates to continue unabated. The AFL-CIO Executive Council approved the allocation of $\$ 13$ million to launch a campaign to defeat Proposition 226. Unions in California made 650,000 phone calls to voters, visited 18,000 work sites, sent 500,000 pieces of mail to union members' homes, and went block by block in 5005 precincts talking to voters face-to- face. The campaign convinced members

30 Mark Bucher, "Strong Majority of California Voters Support Paycheck Protection Initiative," Yes on 226, Press Release, February 27, 1998. Dana Milbank, "California's Proposition 226, a Powerful Threat to Labor's Political Clout, Draws Many Workers," The Wall Street Journal, March 18, 1998, p. A24. 
and other voters that the proposition would silence the voice of labor and allow business to dominate the political scene. Fifty-four percent of the electorate rejected the proposition. Unions have defeated similar paycheck protection propositions in other states as well, and have beaten back most efforts to enact state level laws outlawing contracts that require non-members to pay dues or fees in workplaces with collective bargaining (so-called right to work laws).

But union ability to influence members and other voters in these battles does not necessarily translate into influencing members to support union favored candidates in standard elections. Thirty to forty percent of union members vote Republican. Many belong to the National Rifle Association or other groups whose political agenda usually differs from that of unions. Most union members are relatively high wage workers (in part because of collective bargaining) who might be expected to favor more conservative economic or tax policies than union leaders typically favor. Substantial numbers of union members supported Ronald Reagan in his Presidential bids, though to a lesser extent than nonunion members. The key issue is the magnitude of the union impact on the voting preferences of members. In their analysis of the 1978 election, Delaney, Masters, and Schwochau (1990) found that union members and to a lesser extent nonmembers in union households supported candidates endorsed by the AFL-CIO's Committee on Political Action (COPE) to a substantially greater extent than did otherwise similar persons from nonunion households. By contrast, Clark and Masters (2001) report that while union members favored union candidates in the 1994 Pennsylvania elections enough agreed with the Christian Coalition and National Rifle Association on some union political goals, to have voted against their economic interests to have produced a defeat for unions.

To see how unions affect the voting behavior of union members and persons in union households on a broad set of elections, I use the cumulative NES data files from 1948 to 2000. I 
focus on two issues: the extent to which the political attitudes of union members differ from those of nonunion members with similar characteristics, which I will call the long run impact of unionism; and the extent to which unions alter workers' voting in particular elections conditional on those attitudes, which I call the immediate impact of unionism. Although unions sometimes endorse Republican candidates, in most elections and areas, unions favor the Democrats, so I take voting Democratic as the best measure of the union preferred candidate. First, I estimate an equation in which voter attitudes depend on the socioeconomic characteristics of the voter ( $\mathrm{Zi})$ and their connection to unions:

(3) $\mathrm{ATTi}=\mathrm{cUNIONi}+\mathrm{Zi}+$ ui

Then I estimate an equation relating the decision to vote Democratic to unionism and characteristics:

(4) $\mathrm{DEMi}=\mathrm{a}+\mathrm{b}$ Unioni $+\mathrm{Zi}+\mathrm{ui}$,

Finally, I add the attitude variable to equation (4):

(5) $\mathrm{DEMi}=\mathrm{a}^{\prime}+$ b’ Unioni $+\mathrm{Zi}+\mathrm{c}$ ATTi + ui,

If the union effect on members voting Democratic operates solely through the intervening attitude variable, addition of ATTi to the model would reduce the coefficient on unionism to insignificance, producing a recursive model of the union impact on voting: unionism $->$ attitudes $\rightarrow$ voting. Contrarily, if addition of the attitude variable does not affect the coefficient on unionism, then the union impact will be immediate, dependent on that particular campaign..

To measure attitudes I use the NES's thermometer scales. Thermometer scale questions ask respondents to give a 0 to 100 score on how they view a particular institution or policy. ${ }^{31} \mathrm{I}$

${ }^{31}$ The codebook describes the interviewer statement: "ratings between 50 degrees and 100 degrees mean that you feel favorable ... ratings between 0 degrees and 50 degrees mean that you don’t feel favorable" http://www.umich.edu/ nes/studyres/nes2000/cbk00all.htm 
take the difference between the thermometer score respondents gave the Democratic Party and the thermometer score they give the Republican Party as a measure of the propensity to favor the Democrats. Similarly, I take the difference in the thermometer score each respondent gave to liberalism and the thermometer each gives to conservativism as a measure of liberal attitudes. By taking differences, I eliminate personal scaling factors due to persons giving high or low scores in general. For instance, the difference in scores gives someone who places the Democrats at 30 and Republicans at 40 the same measure as a person who places the Democrats at 60 and Republicans at 70.

Using the NES data, I estimated models based on equations (3) - (5) for the 2000 election and for a pooled sample of all elections from 1948 to 2000. Panel A of Table 7 gives the estimated coefficients (standard errors) on a dummy variable for union membership under different regression specifications. As in previous tables, each coefficient comes from a separate regression with the specified dependent and independent variables. Column 1, which gives the coefficient on unionism in a uni-variate regression, measures the mean difference between union members and non-members on the specified outcome. The first two lines show that union members are more favorable to Democrats vs Republicans and toward liberalism vs conservativism. Addition of demographic characteristics ( age, gender, years of education, race, and household income) in column 2 increases the impact of unions on these attitudinal indicators. This reflects the fact that union members are older, more skilled, and are in the upper half of the income distribution, where persons have more conservative Republican leanings. Unionism moves members to the left of where they would be given their socioeconomic status.

Line 3 of table 7 examines the impact of unionism on members' intentions to vote for the Democratic candidate for President prior to the election. It is taken from the pre-election NES 
survey, in which interviewing begins in September and continues until the day before the election. On average the pre-election data measure voting intentions about one month before the election. In the 2000 election union members were 10 points more likely to intend to vote for the Democratic candidate for President than nonunion members and were 14 points more likely to say they planned to vote for that candidate after controlling for characteristics. But addition of the thermometer variables reduces the coefficient on unionism by 5 percentage points between the column 2 and column 3 regressions. The implication is that much of the union impact on the pre-election intention of members to vote Democratic operates through the longer run impact of unionism on attitudes toward liberalism/conservativism and toward the two parties.

The dependent variables in lines 4 and 5 are dummy variables for voting Democratic. As in the earlier calculations, the coefficient on unionism rises with the addition of demographic covariates and falls with the addition of the thermometer measures. The drop in the union coefficient between column 2 regressions and the column 3 regressions imply that $40-50 \%$ of the union impact on members voting Democratic in house and presidential elections occurs through the thermometer indicators. The existence of a union effect conditional upon the thermometer measures rejects a fully recursive model.

In the column 4 regressions I added to the equation a dummy variable for the voters' intention to vote Democratic in the Presidential vote from the pre-election survey. In this case, the coefficient on unionism for actually voting Democratic falls to insignificance. The implication is that most of the union impact on members voting Democratic occurs prior to election campaigns, either through the union impact on attitudes or on intention to vote. The "immediate" union impact on voting during the campaign period was minimal.

An alternative way to examine the effect of unions on the voting behavior of members 
during the campaign season is to compare the extent to which union members and non-members changed their initial intended vote during the campaign. If unions influenced votes during a campaign, union voters who intended to support the Democrat should be more likely to stay with that candidate than nonunion voters with the same initial intention, while union voters intending to support the Republican should be more likely than nonunion voters intending to vote Republican to shift toward the Democrat. In the 2000 election, the NES data show no such pattern. In $2000,91.3 \%$ of union members who said that they intended to vote for Gore reported voting for him, but $95.2 \%$ of nonunion voters who said they intended to vote for Gore reported doing so. Of the voters who initially favored Bush, $2.9 \%$ of union voters switched to Gore compared to $4.5 \%$ of nonunion voters. Given the small number of union voters in the 2000 NES, these differences are not significant. Still, they indicate that in the last month or so of the campaign, unions did not induce members to switch to the union favored candidate more frequently than nonunion voters switched to the union favored candidate. ${ }^{32}$

In Panel B of table 7, I expand the analysis from the 2000 election to all the elections covered by the NES. The union variable in these regressions relate to having a household member in a union - the standard NES question about unions prior to 1996. By pooling all of the elections from 1948 to 2000 , I greatly increase the sample size, which yields stronger statistical results than are possible with the sample for the 2000 election. Panel B confirms the main finding of panel A that much of the union effect on voting occurs through unionism

${ }^{32}$ These are from my tabulations of the NES data, unweighted. The sample sizes are just 112 union respondents and 975 nonunion respondents. NES data for the 1996 Presidential election also shows insignificant differences between union and nonunion voters in the retention of voters who said they intended to vote for Clinton and in the proportion of union and nonunion voters switching from Dole to Clinton. Again, the sample sizes were small with just 152 union respondents and 923 nonunion respondents. 
affecting long term attitudes. The calculations in columns 1 and 2 show that over the longer period, unions increased the favorableness with which members viewed the Democrats and liberalism relative to Republicans and conservatism. The estimated coefficients on unionism in the line 8 regression on intention to vote for the Democrat for President falls by $60 \%$ from 0.14 to 0.60 between columns 2 and 3, implying that the disproportionate union vote for Democrats operates largely through the thermometer indicators. The column 4 regressions in lines 9 and 10 show that with the larger sample there is a statistically significant union effect on voting Democratic even conditional on intention to vote Democratic, though the magnitude of the coefficient on unionism is just 10-20 percent as large as coefficients in columns (1) and (2).

\section{Union political activity and declining union density}

Union leaders believe that unions affect the voting behavior of members and their families by providing them with information about elections and candidates, particularly through face to face discussions: "Talking to union members is the key". ${ }^{33}$ AFL-CIO data on the 2000 election show that unions contacted $45 \%$ of members at the work site in states targeted for special attention and $28 \%$ of members at work sites in states not so targeted. Ninety-three percent of members said they had received some union contact regarding the election; $;^{34} 69 \%$ of members with " 4 or more contacts" voted for Gore whereas only $61 \%$ of members with " $0-1$ contacts" voted for Gore. Unions estimate that among members receiving "high union information" $76 \%$ voted Democratic in House races compared to $61 \%$ of members with "low union information".

${ }^{33}$ Steve Rosenthal, How Can Labor Impact the Current Political Agenda?'Labor and Worklife Forum January 14, 2003 Harvard University, power point presentation. "The more personal the form of contact the more likely we are to win union members' support".

${ }^{34}$ Rosenthal, op cit. 
Data comparing union and nonunion persons from the NES Post-Election survey tell a similar story. In 2000 the NES asked respondents about their receipt of political messages and campaign participation. These data show that interested groups contacted union members more frequently about the election than they contacted non-members. For example, $45 \%$ of union members compared to $37 \%$ of non-members said that a political party had contacted them about the election; $21 \%$ of union members said that someone else had talked with them about voting or registering to vote compared to $10 \%$ of non-members; $40 \%$ of members said they had received mail about the election compared to $25 \%$ of non-members. The sole exception to the union edge is the use of the Internet, where $49 \%$ of nonunion respondents compared to $36 \%$ of union respondents said that they had seen information on the Internet. With respect to campaign participation, union members also showed greater involvement than non-members: $47 \%$ of unionists said that they tried to influence the vote of others compared to $34 \%$ of non unionists; more union members said that they attended meetings or rallies and contributed money to a political campaign. Consistent with the AFL-CIO evidence, the NES data shows that union members contacted more often or more involved in campaigns were more likely to support the Democrats than members who are less involved. ${ }^{35}$

While both the union and NES data are consistent with the claim that unions affect members' voting by personal contacts and provision of information, neither data set can rule out an alternative explanation - that union activists contact members who are likely to vote and favor union candidates more than members unlikely to vote or opposed to the endorsed candidates. To rule out this explanation for the correlations between voting and contacts requires analysis beyond that in this study: comparisons of voting between campaigns where

\footnotetext{
${ }^{35}$ All of these data are from the 2000 NES.
} 
unions invested substantial efforts in contacting voters and campaigns where unions did little.

Withe low and declining union density, it seems natural to expect union ability to influence turnout and election results to fall over time. However, as long as unions maintain millions of members and allocate resources to politics, they can maintain or increase their impact on elections even with declining density at work places. They can do this by contacting and influencing the millions of non-union persons favorably inclined to unions but whom unions cannot organize under current US labor laws and procedures. To get some notion of the number of non-members who might respond positively to union initiatives, I tabulated the thermometer question regarding unions on the 2000 NES. This question asked respondents "still using the thermometer, how would you rate ... labor unions" as part of a battery of thermometer questions.

Table 8 gives the results of this tabulation. Column 1 shows that most union members have reasonably high valuations of unions. Forty-six percent give unions thermometer scores from 80 to 100 and just 15 percent give unions low scores below 40. Column 2 shows that just 16 percent of non-union members give unions thermometer scores above 80 while $28 \%$ give unions scores below 40. The key finding, however, is not that union members have higher opinions of unions than non-members, but that because union density is so low, non members make up the vast bulk of persons with highly favorable views of unions. Column 3 shows that $80 \%$ of voters who rate unions in the $81-100$ thermometer range and $73 \%$ of those who rate unions at 100 are non-members. Since the NES reported an especially low union share of voters, the proportion of persons giving high marks to unions is probably a bit lower than in the NES survey, but declines in the nonunion proportion of NES respondents of 5 or so percent would still leave non members as the vast majority of persons with highly favorable views to unions. Who are these non-union persons favorable to unions? My tabulations of the 2000 NES 
show that some are non-members in union households but that $91 \%$ are in households where no one is a union member. These pro-union persons are more likely to be black and less educated and to have lower household income than the average non-union person. They are disproportionately likely to view themselves as average working class persons. ${ }^{36}$ They are less likely to vote than union members, which makes them a potentially good target for get-out-thevote drives. ${ }^{37}$ Recognizing the need to influence non-union members in the political sphere, the AFL-CIO developed in 2003 a program to engage nonunion members about national policies in selected communities - Working America.${ }^{38}$ Modern information, communication, technology - notably the low cost of reaching people through the Internet - makes it technically and financially feasible for unions to reach pro-union non members and to try to enlist their active support for union positions in political campaigns. By itself, this may not help unions to reverse the downward trend in collective bargaining representation at workplaces, but it could lead to unions delivering other information to persons without collective bargaining contracts, for

${ }^{36}$ Blacks are more than twice as likely to give unions a high score. Of those giving unions a high score $58 \%$ are high school graduates or less, compared to $37 \%$ of the sample. Similarly $49 \%$ of those giving unions a high thermometer rate themselves as working class compared to $35 \%$ of the sample; $9.2 \%$ of nonunion persons in a union household give unions a high thermometer, while they make up $6.2 \%$ of the sample.

${ }^{37}$ Among persons who answered the thermometer question, nonunion persons who give unions an 81-100 thermometer score had a voting rate of $69 \%$ compared to a $72 \%$ voting rate for other nonunion persons and an $84 \%$ voting rate for union persons. The high rates show the over reporting bias in the NES survey.

${ }^{38} \mathrm{http}$ ///www.aflcio.org/aboutaflcio/ecouncil/ec08062003f.cfm. Also see Greenhouse, Steven, A.F.L.-C.I.O. Begins Group for Workers Not in Unions, NY Times, http://www.nytimes.com/2003/08/29/national/29LABO.html. Another union effort focused on non-union households, Working America, the Partnership for America's Family, a Section 27 non-profit organization, which sought to increase turnout foundered due to infighting among union leaders. Harry Kelber "Partnership's Election Role Endangered as Top AFL-CIO Political Leaders Resign" The Labor Educator, June 4, 2003, www.laboreducator.org/partelec.htm 
instance on issues relevant to their workplace, and ultimately to create a broader union movement in the US of the open source unionism form that Freeman and Rogers $(2002,2003)$ have proposed - as opposed to unionism based primarily on the attainment of majority status collective bargaining contracts, per the CPS definition.

\section{Conclusion}

Using data on unionism and voting in four different data sets, this study has found that the voting rate of union members averages some 12 points above that of non-union members; and that the voting rate of nonunion persons in union households averages 3 points above that of persons in nonunion households. Most of the higher rate of turnout of unionists is due to socioeconomic factors that differentiate union members from others, but there remains a union voting premium for both members and other persons in union households. The difference in turnout between members and non-members with comparable characteristics is about 4 percentage points. The data reject the claim based on exit poll data that the union share of the electorate rose massively in the 1990s. But analysis of the number of retired union members and other nonemployed persons who identify with unions show that the union share of voters in unions and in union households in 2000 is closer to the exit poll estimates than to CPS based estimates. The exit polls give a reasonably accurate measure of the level of union share of voting but not of the 1990s trend in that share.

With respect to voting preferences, this study has found that union members are more likely to vote for a Democrat for the House or Presidency than demographically comparable nonunion voters, largely because union members have attitudes and voting inclinations favorable to the Democrats and to liberalism prior to a given campaign. From this perspective union political activity is more of an investment in long run political influence rather than delivery of 
votes in a particular election. Finally, this study has identified a sizable group of nonunion persons with pro-union attitudes that unions could potentially influence to maintain the union impact on elections, even though these persons cannot gain collective bargaining contracts. 


\section{References}

Casper, Lynne, and Loretta Bass. 1998. "Voting and Registration in the Election of November 1996." Current Population Reports, series P20, no.504 (July). Washington: U.S. Government Printing House for U.S. Bureau of the Census.

Chang, Tracy F. 2001 “ The Labour Vote in US National Elections, 1948-2000”, The Political Quarterly 72, no 3, 375-385

Chang, Tracy F. “ Electoral Activities of Southern Local Unions in the 2000 Election” 2003 Labor Studies Journal vol 28 no 1(Spring 2003); 53-81.

Clark, Paul and Marick F. Masters (2001) “Of General Interest Competing Interest Groups and Union Members Voting” Social Science Quarterlym Volume 82 Issue 1 pp 105 - 116

Dark, Taylor, The Unions and the Democrats: an enduring alliance, Ithaca NY, Cornell, 1999

Day, Jennifer, and Avalaura Gaither. 2000. "Voting and Registration in the Election of November 1998." Current Population Reports, series P20-523RV (August). Washington: U.S. Government Printing House for U.S. Bureau of the Census.

Delaney, John, Jack Fiorito, and Marick Masters "The effects of organizational and environmental characteristics on union political action” American Journal of Political Science vol 32, issue 3 (Aug 1988), 616-642

DeLaney, John, Marick Masters, and Susan Schwochau 1988 "Unionism and Voter Turnout" Journal of Labor Research vol 9 no 3, 221-236

Delaney, John, Jack Fiorito, and Paul Jarley 1999 "Evolutionary Politics? Union Differences and Political Activities in the 1990s Journal of Labor Research vol 20 no 3, 277-96

Delaney, John 1991 "The future of unions as political organizations" Journal of Labor Research vol 12, no 4 373-385

Fields, Mitchell, Marick Masters, and James Thacker 1987 “Union Commitment and Membership Support for Political Action: an exploratory analysis" Journal of Labor Research vol 13, no 2, 141-157

Freeman, Richard and Medoff, James (1984) What Do Unions Do? Basic Books, NY

Freeman, Richard and Joel Rogers (2002) “A Proposal to American Labor” The Nation, June 24, $2002 \mathrm{http}: / /$ www.thenation.com/doc.mhtml\%3Fi=20020624\&s=rogers

Freeman, Richard and Joel Rogers (2002) "Open Source Unionism: Beyond Exclusive Collective Bargaining", Working USA, Spring, volume 6. No 1, Gerber, Alan and Donald Green. 2000. "The Effects of Canvassing, Telephone Calls, and Direct 
Mail on Voter Turnout: a field experiment.” American Political Science Review 94: 653-63.

Jamieson, Amis, Hyon B. Shin, and Jennifer Day. 2002. "Voting and Registration in the Election of November 2000.” Current Population Reports, series P20, no.542. Washington: USGPO

Juravich, Tom and Peter Shergold (1988) "The Impact of Unions on the Voting Behavior of their members", Industrial and Labor Relations Review, 1988, pp 374-85

Lipjhat, Arend.1997 . “Unequal Participation: Democracy’s Unresolved Dilemma.” American Political Science Review 91: 1-15.

Marick F. Masters and John Thomas Delaney. "Union Political Activities: A Review of the Empirical Literature." Industrial and Labor Relations Review, Vol. 40, No. 3 (April 1987), pp. 336-353.

McDonald, Michael. 2003. "On the Over-Report Bias of the National Election Study Turnout Rate."Political Analysis, forthcoming.

McKee, Seth. 2002. "Was Turnout Significantly Higher in the Battleground States in the 2000 Presidential Election?" Paper presented to the 2002 Annual Meeting of the American Political Science Association. Boston (September 24-28, 2002).

Radcliff, Benjamin, and Patricia Davis. 2000. "Labor Organization and Electoral Participation in Industrial Democracies." American Journal of Political Science 44(1) (January): 132-41.

Radcliff, Benjamin. "Organized Labor and Electoral Participation in American National Elections." Journal of Labor Relations 22, no. 2 (2001).

Rogers, Joel and Ruy Teixera (2001) America's Forgotten Majority: Why the White Working Class Still Matters NY: Basic Books

Rosenstone, Steven, and John Hansen. 1993. Mobilization, Participation, and Democracy in America. NY: Macmillan.

Silver, Brian, Barbara Anderson, and Paul Abramson. 1986. "Who Overreports Voting?" American Political Science Review, 80(2) (June): 613-24.

Teixeira, Ruy A. 1992. The Disappearing American Voter. Washington D.C.: Brookings.

Verba, Sidney, Kay Schlozman, Henry Brady. 1996. Voice and Equality: Civic Voluntarism in American Politics. Cambridge: Harvard University Press.

Marvin Wattenberg. 2002. Where Have All the Voters Gone? Cambridge: Harvard University Press.

Wolfinger, Raymond and Steven Rosenstone. 1980. Who Votes? New Haven Yale University Press. 
Table 1: Percentage of Voters Who are Union Members or Who are in a Household with a union member, 1990-2000

\begin{tabular}{lcccccccc} 
& \multicolumn{3}{c}{ Union Members } & \multicolumn{5}{c}{ in Union Households } \\
\cline { 2 - 9 } & VNS & CPS & NES & GSS & VNS & CPS & NES & GSS \\
\cline { 2 - 10 } & 16 & 11 & 10 & $\%$ & 26 & 19 & 17 & $\%$ \\
1998 & $\%$ & 11 & 14 & $\%$ & 23 & 19 & 21 & $\%$ \\
1996 & $\%$ & 11 & 14 & 14 & 24 & 20 & 21 & 19 \\
1994 & $\%$ & 13 & $\%$ & $\%$ & 14 & NA & 21 & $\%$ \\
1990 & $\%$ & 11 & $\%$ & 14 & 18 & 20 & 18 & 19
\end{tabular}

SOURCE: Tabulated from VNS exit polls for 1992 (ICPSR 6102); 1994(ICPSR, 6520), 1996 (ICPSR, 6989); 1998 (ICPSR, 2780); 2000, (ICPSR, 3527). Current Population Survey November Voting

Supplements for Out-going Rotation Group; National Election Studies 1948-2000 NES Cumulative Data file, (www.umich.edu/ nes/studyres/nes48_00/nes48_00.htm)

General Social Survey 1972-2000 Cumulative, www.icpsr.umich.edu/GSS/

The CPS household estimates obtained by forming households using the household identification code in the CPS.

a In 1990 VNS did not exist, so this figure is from predecessor exit poll by CBS News/New York Times General Exit poll 1990, ICPSR 9602.

NA -No estimate is possible because between June and December 1994 sample redesigns by the Census led to a scrambling of the household identification number. 
Table 2: VNS and Earlier Exit Poll Questions on Union Status, and Percentages of Rerspondents in Households with Union Members, Presidential Year Elections, 1984-2000

Panel A: VNS Exit Poll
Source Year Percentage

of Voters in

Union

Households

Do you or does anyone in your household belong to a labor union? (Responses: Self; Someone else; Self and Someone else)

Do you or does someone in your household belong to a labor union? Responses: (yes or no separate item)

Do any of the following apply to you (list of 9 items)

Someone in household belongs to a labor union (yes or no)

\section{Panel B: Prior Exit Polls}

Are you or is any person living in your household a member of a labor union? Response (Self; Other family member)

Do any of the following describe you Member of union household? (List of 14 items) Response: check yes, no chance to respond no on individual items

Is respondent or anyone in respondent's household a union member? Response (yes, no)
26.7

VNS
exit polls

2000

.

exit polls

VNS

1996

24.6

exit polls

VNS

1992

18.7 exit polls

(

$\begin{array}{ccc}\text { CBS } & 1998 & 26.6 \\ & & \\ \text { ABC } & 1988 & 9.9\end{array}$

$\mathrm{ABC} \quad 1984 \quad 26.9$

SOURCE: $\quad$ VNS exit polls for 1992 (ICPSR 6102); 1996 (ICPSR, 6989); 2000 (ICPSR 3527). ABC News General Election exit polls: 1984, ICSPR 8416 1988, ICSPR 9118. CBS News/New York Times General Exit poll 1988, ICPSR 9138. Percentages are unweighted in this table 
Table 3: Percentage of Voters Who Are Union Members, by Employment Status and age, 2000

\section{Employed}

$18-24$

25-29

30-39

40-44

45-49

50-59

60-64

65-74

$75+$

Not Employed*

18-24

25-29

30-39

40-44

45-49

50-59

60-64

65-74

$75+$

Retired

\begin{tabular}{cccc} 
VNS & CPS & NES & GSS (1996) \\
\hline 17.9 & 18.2 & 11.6 & 16.2
\end{tabular}

15.1

7.1

0.0

10.0

16.4

14.9

10.0

13.4

\section{8}

15.9

14.2

13.4

17.3

20.8

10.5

13.5

21.6

21.7

13.5

23.5

19.9

25.0

14.6

20.0

22.1

19.3

5.1

25.0

16.9

10.6

3.3

4.4

18.3

0.0

\}. 5

10.3

$\%$

7.5

9.9

7.5

$\%$

9.1

0.0

17.2

$\%$

11.1

7.1

$$
7.8
$$

$\%$

8.2

3.0

11.1

$\%$

9.4

0.0

13.0

$\%$

8.7

12.5

10.6

$\%$

7.3

15.0

13.4

$\%$

0.0

11.6

\section{3}

$\%$

9.0

9.7

$\%$

6.5

11.2

$\%$

$\%$

8.6

16.6

SOURCE: Tabulated from 2000 VNS exit poll; November 2000 CPS Voter Supplement File Out-going rotation group; National Election Studies Survey 2000; General Social Survey 1996. All data are weighted by appropriate survey weights.

* In the VNS, $41.3 \%$ of nonemployed union voters are aged 60 and over; in the NES, $41.7 \%$ of non employed union voters are aged 60 and over and $50 \%$ of the non employed union voters are retirees; in the GSS, $75.0 \%$ of non employed union voters are aged 60 and over and $69.4 \%$ are retirees. 
Table 4: Percentage of Persons Who Vote and Differences in Percentage Voting, by Union Status and Employment Status CPS files, 1990-2000

\section{A. Percentages of Persons Who Vote}

\section{Employed}

\begin{tabular}{|c|c|c|c|c|c|c|c|c|}
\hline & $\begin{array}{l}\text { Union } \\
\text { Members } \\
\text { (1) }\end{array}$ & $\begin{array}{c}\text { All } \\
\text { Nonunion } \\
\text { Employed } \\
\text { Persons } \\
(2) \\
\end{array}$ & $\begin{array}{l}\text { Nonunion } \\
\text { Employed } \\
\text { persons in } \\
\text { Union } \\
\text { Household } \\
\quad(3)\end{array}$ & $\begin{array}{c}\text { Nonunion } \\
\text { Employed } \\
\text { Persons in } \\
\text { Nonunion } \\
\text { Household } \\
\quad(4)\end{array}$ & $\begin{array}{c}\text { Non } \\
\text { employed } \\
\text { Persons in } \\
\text { Union } \\
\text { Household } \\
\quad(5) \\
\end{array}$ & $\begin{array}{c}\text { Non } \\
\text { employed } \\
\text { Persons in } \\
\text { Nonunion } \\
\text { Household } \\
\quad(6)\end{array}$ & $\begin{array}{c}\text { All } \\
\text { Persons in } \\
\text { Union } \\
\text { Household } \\
\\
(7)\end{array}$ & $\begin{array}{l}\text { All } \\
\text { Persons in } \\
\text { Nonuion } \\
\text { Household } \\
\text { (8) }\end{array}$ \\
\hline 2000 & 68.3 & 58.0 & 62.0 & 57.5 & 59.0 & 58.2 & 64.8 & 57.8 \\
\hline 1998 & 55.2 & 40.6 & 45.8 & 40.0 & 46.3 & 48.6 & 50.9 & 44.0 \\
\hline 1996 & 67.1 & 55.3 & 59.1 & 54.8 & 56.9 & 58.5 & 62.9 & 56.6 \\
\hline 1994 & 59.6 & 44.9 & -- & -- & -- & -- & -- & -- \\
\hline 1992 & 73.9 & 66.2 & 68.0 & 65.9 & 59.5 & 65.0 & 69.4 & 65.5 \\
\hline 1990 & 54.7 & 44.9 & 50.1 & 44.1 & 41.3 & 52.0 & 50.7 & 48.1 \\
\hline $\begin{array}{l}\text { Ave, } \\
\text { pres yr }\end{array}$ & 69.8 & 59.8 & 63.0 & 59.4 & 58.5 & 60.7 & 65.7 & 60.0 \\
\hline $\begin{array}{l}\text { Ave, } \\
\text { other } \\
\text { yrs }\end{array}$ & 56.5 & 43.5 & 48.0 & 42.1 & 43.3 & 50.3 & 50.8 & 46.1 \\
\hline
\end{tabular}

SOURCE: November CPS Voter Supplement Files for outgoing rotation group with observations weighted by sample weight. Averages are unweighted means of the voting rates for the individual years. 
Table 5: Coefficients and Standard Errors for Estimates of the Impact of Union Membership on Voting, Employed Persons only CPS, 1990-2000

\begin{tabular}{|c|c|c|c|c|c|c|}
\hline Sample & $\begin{array}{c}\text { No } \\
\text { Covariates }\end{array}$ & $\begin{array}{l}\text { Demographic } \\
\text { Covariates }\end{array}$ & $\begin{array}{c}(2)+ \\
\text { Job } \\
\text { Covariates } \\
\end{array}$ & $\begin{array}{c}(3)+ \\
\text { Family } \\
\text { Income }\end{array}$ & $\begin{array}{c}\qquad(4)+ \\
\text { Other Adult's } \\
\text { Characteristics }\end{array}$ & $\begin{array}{c}\text { Number of } \\
\text { Observations }\end{array}$ \\
\hline $\begin{array}{l}\text { 1. All Employed, } \\
\text { by year }\end{array}$ & (1) & (2) & (3) & (4) & (5) & \\
\hline 2000 & $\begin{array}{l}.09 \\
(.01)\end{array}$ & $\begin{array}{c}.06 \\
(.01)\end{array}$ & $\begin{array}{l}.05 \\
(.01)\end{array}$ & $\begin{array}{c}.04 \\
(.01)\end{array}$ & -- & 11976 \\
\hline 1998 & $\begin{array}{l}.16 \\
(.01)\end{array}$ & $\begin{array}{l}.11 \\
(.02)\end{array}$ & $\begin{array}{l}.07 \\
(.01)\end{array}$ & $\begin{array}{l}.06 \\
(.01)\end{array}$ & -- & 12094 \\
\hline 1996 & $\begin{array}{l}.11 \\
(.01)\end{array}$ & $\begin{array}{l}.07 \\
(.01)\end{array}$ & $\begin{array}{l}.05 \\
(.01)\end{array}$ & $\begin{array}{l}.04 \\
(.01)\end{array}$ & -- & 11876 \\
\hline 1994 & $\begin{array}{l}.15 \\
(.01)\end{array}$ & $\begin{array}{l}.10 \\
(.01)\end{array}$ & $\begin{array}{l}.07 \\
(.01)\end{array}$ & $\begin{array}{c}.06 \\
(.01)\end{array}$ & -- & 13246 \\
\hline 1992 & $\begin{array}{l}.08 \\
(.01)\end{array}$ & $\begin{array}{c}.05 \\
(.01)\end{array}$ & $\begin{array}{l}.04 \\
(.01)\end{array}$ & $\begin{array}{c}.03 \\
(.01)\end{array}$ & -- & 13177 \\
\hline 1990 & $\begin{array}{l}.11 \\
(.01)\end{array}$ & $\begin{array}{c}.07 \\
(.01)\end{array}$ & $\begin{array}{l}.04 \\
(.01)\end{array}$ & $\begin{array}{c}.03 \\
(.01)\end{array}$ & -- & 13252 \\
\hline \multicolumn{7}{|l|}{$\begin{array}{l}\text { Pooled Sample, } \\
1990-2000^{\mathrm{a}}\end{array}$} \\
\hline 2. All employed & $\begin{array}{c}.12 \\
(.005)\end{array}$ & $\begin{array}{c}.07 \\
(.004)\end{array}$ & $\begin{array}{c}.06 \\
(.005)\end{array}$ & $\begin{array}{c}.04 \\
(.005)\end{array}$ & -- & 77151 \\
\hline $\begin{array}{l}\text { 3. Union and } \\
\text { employed } \\
\text { nonunion in non } \\
\text { union hhlds }\end{array}$ & $\begin{array}{c}.11 \\
(.005)\end{array}$ & $\begin{array}{c}.08 \\
(.005)\end{array}$ & $\begin{array}{c}.06 \\
(.005)\end{array}$ & $\begin{array}{c}.05 \\
(.005)\end{array}$ & -- & 58200 \\
\hline $\begin{array}{l}\text { 4. All Employed } \\
\text { in } 2 \text { adult hhlds }\end{array}$ & $\begin{array}{l}.11 \\
(.01)\end{array}$ & $\begin{array}{c}.08 \\
(.01)\end{array}$ & $\begin{array}{l}.06 \\
(.01)\end{array}$ & $\begin{array}{l}.05 \\
(.01)\end{array}$ & $\begin{array}{l}.05 \\
(.01)\end{array}$ & 37416 \\
\hline
\end{tabular}

SOURCE: Estimated by linear regression from November CPS, with dummy variables for covariates: Demographic: 9 age groups, 5 education groups, race and sex, 9 region groups; Occupation covariates, 141 digit occupation groups; 7 class of occupation groups. Family income, 15 groups, as described in appendix B.

a- Includes dummy variables for year b -1994 excluded because June and December 1994 sample redesigns by the Census scrambled household identification numbers. 
Table 6: Coefficients and Standard Errors for Estimates of the Impact of Being in a Union Household on the Voting of Nonunion Members, CPS, 1990-2000, Pooled Sample of Persons in two Adult Households ${ }^{\mathrm{a}}$

\begin{tabular}{|c|c|c|c|c|c|c|}
\hline \multirow[t]{2}{*}{ Sample } & $\begin{array}{c}\text { No } \\
\text { Covariates }\end{array}$ & $\begin{array}{c}\text { Demographic } \\
\text { Covariates }\end{array}$ & $\begin{array}{c}(2)+\text { Job } \\
\text { Covariates }\end{array}$ & $\begin{array}{c}(3)+ \\
\text { Household } \\
\text { Income } \\
\end{array}$ & $\begin{array}{c}\text { (4) }+ \text { Other } \\
\text { Adult's } \\
\text { Characteristics } \\
\end{array}$ & $\begin{array}{c}\# \text { of } \\
\text { Observation } \\
\text { s } \\
\end{array}$ \\
\hline & (1) & (2) & (3) & (4) & (5) & \\
\hline $\begin{array}{l}\text { 1. All } \\
\text { persons not in } \\
\text { union: }\end{array}$ & $\begin{array}{c}.03 \\
(.01)\end{array}$ & $\begin{array}{l}.05 \\
(.01)\end{array}$ & $\begin{array}{l}.05 \\
(.01)\end{array}$ & $\begin{array}{c}.03 \\
(.01)\end{array}$ & $\begin{array}{c}.02 \\
(.01)\end{array}$ & 59,640 \\
\hline $\begin{array}{l}\text { 2. Employed } \\
\text { persons not in } \\
\text { union }\end{array}$ & $\begin{array}{c}.07 \\
(.01)\end{array}$ & $\begin{array}{c}.06 \\
(.01)\end{array}$ & $\begin{array}{c}.06 \\
(.01)\end{array}$ & $\begin{array}{c}.04 \\
(.01)\end{array}$ & $\begin{array}{c}.03 \\
(.01)\end{array}$ & 30,835 \\
\hline $\begin{array}{l}\text { 3. Non } \\
\text { Employed } \\
\text { persons not in } \\
\text { union }\end{array}$ & $\begin{array}{l}-.02 \\
(.01)\end{array}$ & $\begin{array}{l}.04 \\
(.01)\end{array}$ & $\begin{array}{l}.05 \\
(.01)\end{array}$ & $\begin{array}{c}.02 \\
(.01)\end{array}$ & $\begin{array}{c}.02 \\
(.01)\end{array}$ & 28,805 \\
\hline
\end{tabular}

SOURCE: Estimated by linear regression from November CPS.

a - 1994 Excluded from pooled sample because no estimate is possible due to Census sample redesigns that scrambled family ids. 
Table 7: Estimates of the Impact of Unionism on Voting Democratic, NES, 1948-2000

\begin{tabular}{|c|c|c|c|c|}
\hline & No Covariates & $\begin{array}{l}\text { Demographic } \\
\text { Covariates }\end{array}$ & $\begin{array}{c}\text { (2) }+ \text { Thermometer } \\
\text { Covariates }\end{array}$ & $\begin{array}{c}\text { (3) + Intended } \\
\text { Presidential Vote }\end{array}$ \\
\hline & (1) & (2) & (3) & (4) \\
\hline & \multicolumn{4}{|c|}{ PANEL A: Election 2000: Union Variable is Own Membership } \\
\hline $\begin{array}{l}\text { 1. Thermometer Attitudes } \\
\text { Democrat-Republican }\end{array}$ & $\begin{array}{l}5.78 \\
(3.44)\end{array}$ & $\begin{array}{c}9.32 \\
(3.36)\end{array}$ & & \\
\hline $\begin{array}{l}\text { 2. Thermometer Attitudes } \\
\text { Liberal-Conservative }\end{array}$ & $\begin{array}{l}7.31 \\
(2.92)\end{array}$ & $\begin{array}{c}8.51 \\
(2.94)\end{array}$ & & \\
\hline $\begin{array}{l}\text { 3. Intended Presidential Vote } \\
\text { for Democrats }\end{array}$ & $\begin{array}{l}.10 \\
(.05)\end{array}$ & $\begin{array}{l}.14 \\
(.04)\end{array}$ & $\begin{array}{c}.09 \\
(.04)\end{array}$ & \\
\hline $\begin{array}{l}\text { 4. House Vote for } \\
\text { Democrats }\end{array}$ & $\begin{array}{l}.11 \\
(.05)\end{array}$ & $\begin{array}{l}.13 \\
(.05)\end{array}$ & $\begin{array}{l}.08 \\
(.04)\end{array}$ & $\begin{array}{c}.04 \\
(.04)\end{array}$ \\
\hline \multirow[t]{2}{*}{$\begin{array}{l}\text { 5. Presidential Vote for } \\
\text { Democrats }\end{array}$} & $\begin{array}{c}.09 \\
(.05)\end{array}$ & $\begin{array}{l}.12 \\
(.05)\end{array}$ & $\begin{array}{l}.06 \\
(.04)\end{array}$ & $\begin{array}{l}-.02 \\
(.03)\end{array}$ \\
\hline & \multicolumn{4}{|c|}{ PANEL B: Elections, 1948-2000: Union Variable is Union Household } \\
\hline $\begin{array}{l}\text { 6. Thermometer Attitudes } \\
\text { Democrat-Republican }\end{array}$ & $\begin{array}{l}8.7 \\
(.6)\end{array}$ & $\begin{array}{l}10.8 \\
(.6)\end{array}$ & & \\
\hline $\begin{array}{l}\text { 7. Thermometer Attitudes } \\
\text { Liberal-Conservative }\end{array}$ & $\begin{array}{l}4.3 \\
(.4)\end{array}$ & $\begin{array}{l}5.5 \\
(.5)\end{array}$ & & \\
\hline $\begin{array}{l}\text { 8. Intended Presidential } \\
\text { Vote for Democrats }\end{array}$ & $\begin{array}{l}.13 \\
(.01)\end{array}$ & $\begin{array}{l}.14 \\
(.01)\end{array}$ & $\begin{array}{l}.06 \\
(.01)\end{array}$ & \\
\hline $\begin{array}{l}\text { 9. House Vote for } \\
\text { Democrats }\end{array}$ & $\begin{array}{l}.14 \\
(.01)\end{array}$ & $\begin{array}{l}.13 \\
(.01)\end{array}$ & $\begin{array}{l}.05 \\
(.01)\end{array}$ & $\begin{array}{l}.03 \\
(.01)\end{array}$ \\
\hline $\begin{array}{l}\text { 10. Presidential Vote for } \\
\text { Democrats }\end{array}$ & $\begin{array}{l}.16 \\
(.01)\end{array}$ & $\begin{array}{l}.15 \\
(.01)\end{array}$ & $\begin{array}{c}.06 \\
(.01)\end{array}$ & $\begin{array}{c}.02 \\
(.01)\end{array}$ \\
\hline
\end{tabular}

SOURCE: National Election Studies 1948-2000 NES Cumulatived Data file. Sample sizes vary depending on the panel and variable. For 2000, they range from 832 to 1731, with high value for pre-election variables and the lowest for voting for the house. For 1996, they range from 860 to 1637. For all elections they vary from 5240 to 23789. 
Table 8: Union Thermometer Scores by Union Status

\begin{tabular}{lccc} 
& \multicolumn{2}{c}{ Distribution of Scores } & $\begin{array}{c}\text { Percentage } \\
\text { Score }\end{array}$ \\
\hline $0-20$ & Union member & Nonunion & $94 \%$ \\
$21-40$ & 6.1 & 9.7 & $96 \%$ \\
$41-60$ & 8.4 & 18.4 & $93 \%$ \\
$61-80$ & 30.4 & 40.3 & $89 \%$ \\
$81-100$ & 25.9 & 20.6 & $80 \%$ \\
100 & 29.6 & 11.6 & $73 \%$
\end{tabular}

SOURCE: Tabulated from National Election Studies, 2000, variable 001312, with total sample of 1468, of whom 132 are union members 
Appendix Table A: Percentage Votes Validated by Union Status and Sample Size in Parenthesis, National Election Studies, 1964, 1976-1990

\begin{tabular}{lll} 
& Union & \multicolumn{1}{c}{$\begin{array}{c}\text { Nonunion } \\
1964\end{array}$} \\
$81.2(314)$ & $82.2(957)$ \\
1976 & $86.0(519)$ & $82.8(1736)$ \\
1978 & $79.7(581)$ & $73.8(1666)$ \\
1980 & $83.9(331)$ & $83.3(959)$ \\
1984 & $87.3(358)$ & $86.1(1260)$ \\
1986 & $83.0(316)$ & $82.3(1208)$ \\
1988 & $85.4(270)$ & $85.3(1090)$ \\
1990 & $84.5(251)$ & $82.8(1110)$ \\
& & 82.3
\end{tabular}

SOURCE: Tabulated from NES 


\section{Appendix Table B: Definitions of Covariates used in CPS Regressions}

9 Age Groups: <24, 25-29, 30- 39, 40-44, 45-49, 50-59, 60-64, 65-74, 75+

5 Education Groups: $<12$ years, HS Grad, Some College, College Grad, Post College

2 Race Groups: White, Nonwhite

2 Sex Groups: Male, Female

9 Region Groups: New England, Mid Atlantic, East North Central West North Central, South Atalantic Division, East South Central, West South Central Mountain, Pacific. (Based on first digit of state code)

14 One digit Occupations: Armed forces; Executive; Professional; Technician; Sales; Admin support; Private Household; Protective Service; Other Service; Precision Production craft and repair; Machine operators; Transportation;. Handlers; Farming

7 Class of Occupation groups: Missing; Federal Govt; State Govt; Local Govt; Private; Self Employed-incorp; Self Employed- not incorp

15 Family Income Groups: No income; <\$5,000; \$5,000-7,4900;. \$7,500-9,999;. \$1,000-12,499; \$12,500-14,999; \$15,000-19,999; \$20,000-24,999; \$25,000-29,999; \$30,000-34,999;

$\$ 35,000-39,999 ; \quad \$ 40,000-49,999 ; \$ 50,000-59,000 ; \$ 60,000-74,999 ; \$ 75,000+$ 
Figure 1: Percent of Voters in Union Household, 1992-2000, VNS Exit Polls

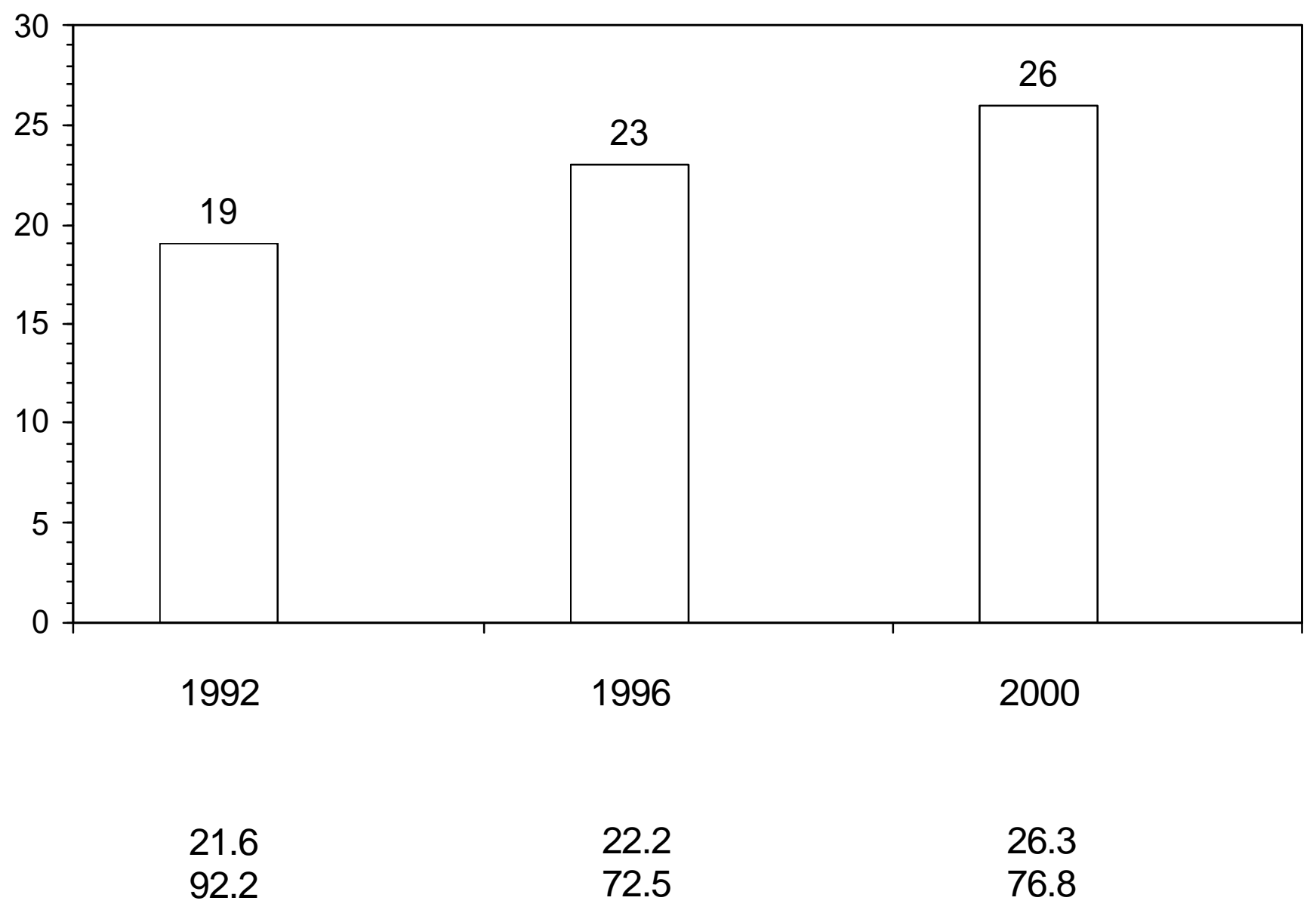

SOURCE: Tabulated from VNS Exit Polls 
Figure 2A: Percent Voting, Persons in Union and Non-Union Households, NES

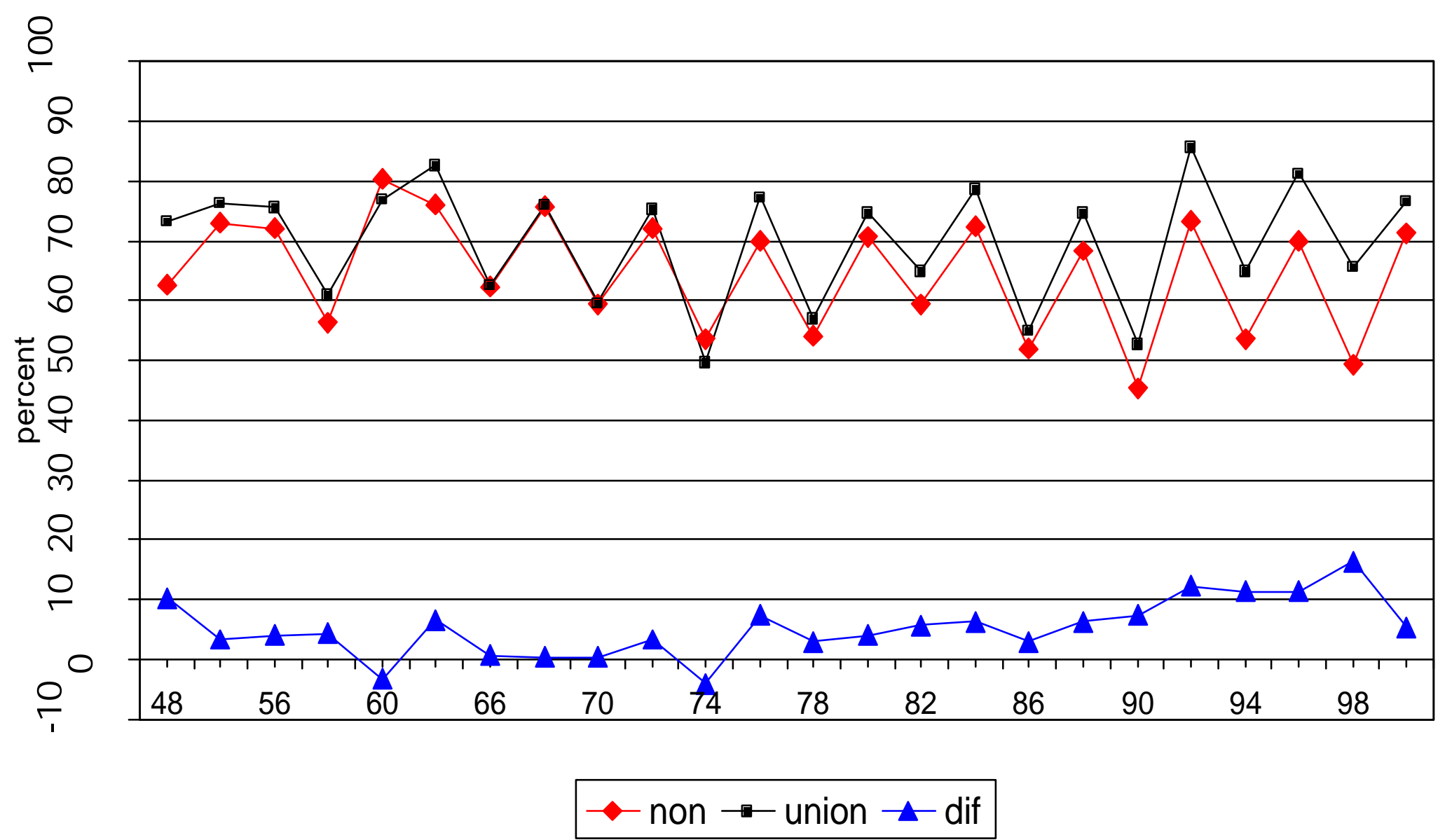

SOURCE: Tabulated from General Social Survey, 1968-1996 
Figure 2B: Percent Voting, Union and Non-Union Members, GSS

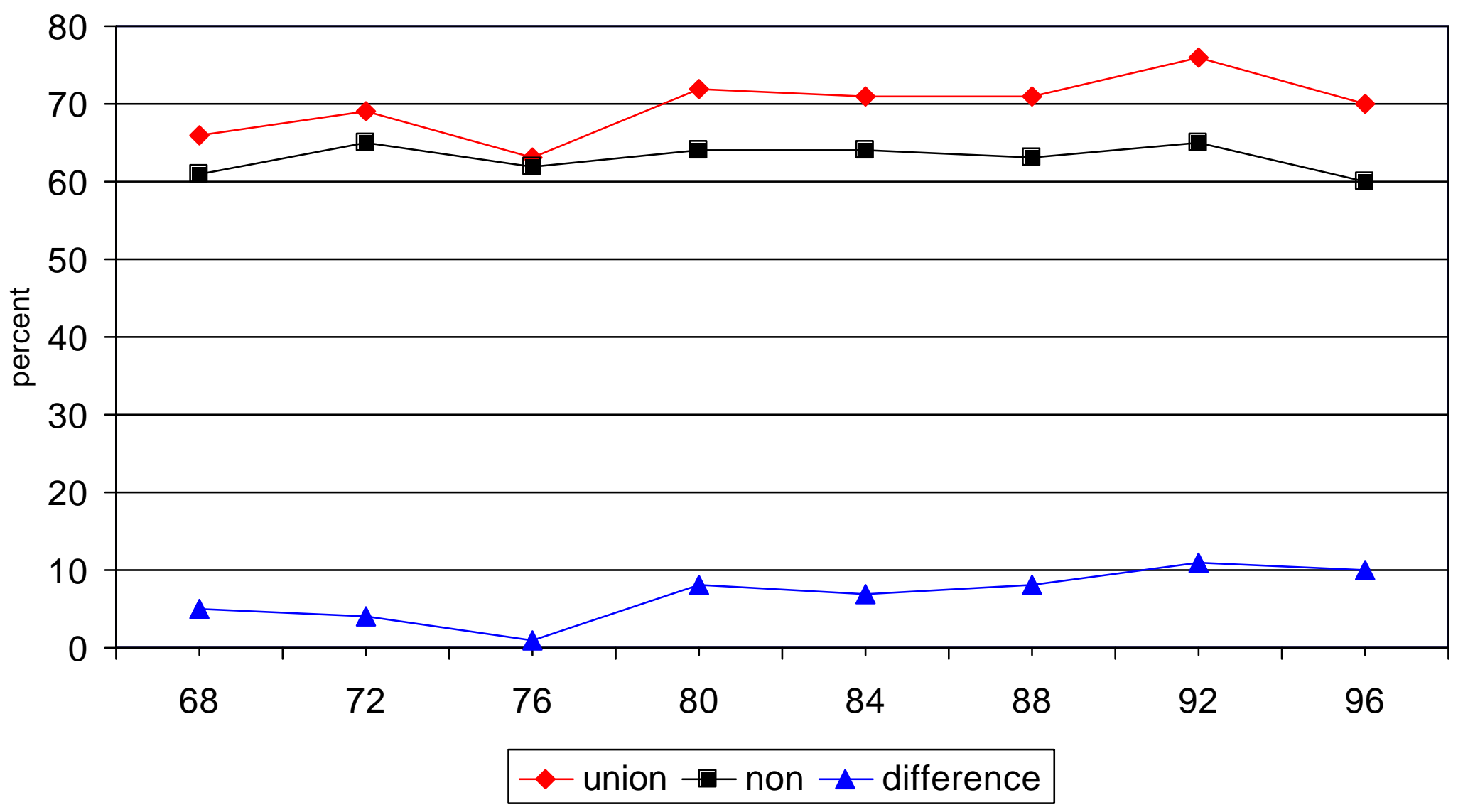

SOURCE: Tabulated from National Election Study, cumulative files, 1948-2000 
Figure 3: Proportion of VNS Respondents Who Voted Democratic, by Union and Employment Status, 2000

\section{Voted for President}

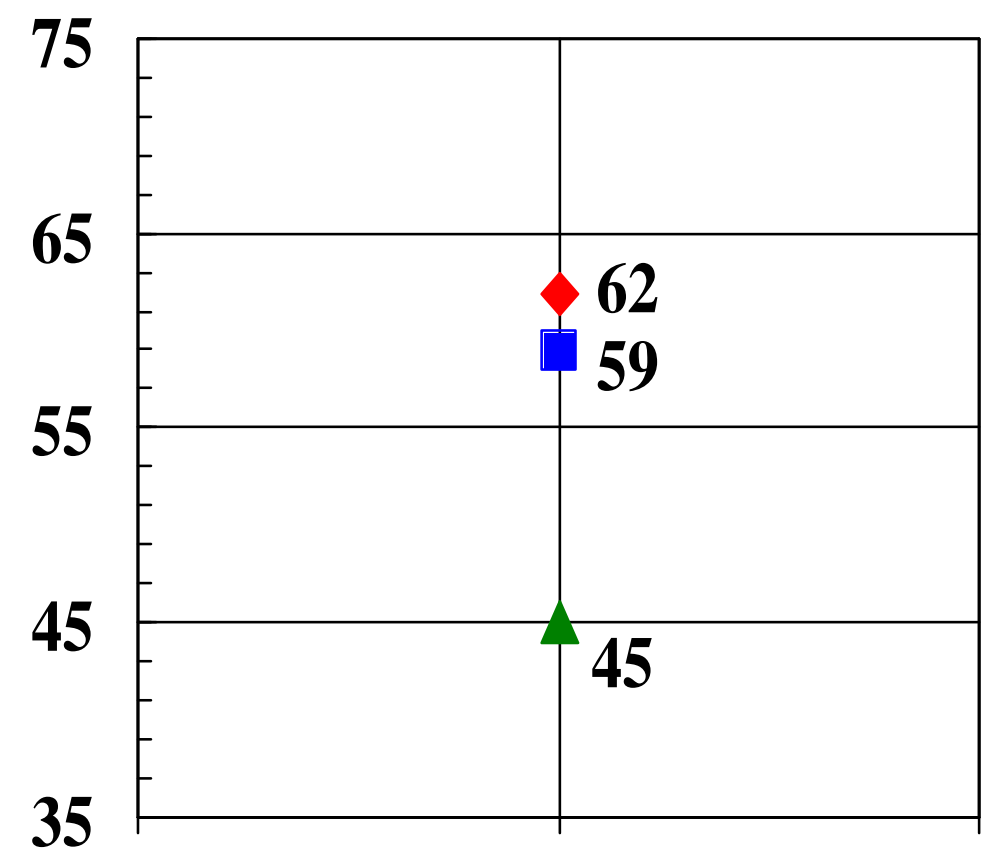

$\diamond$ union employed
Voted for Congress

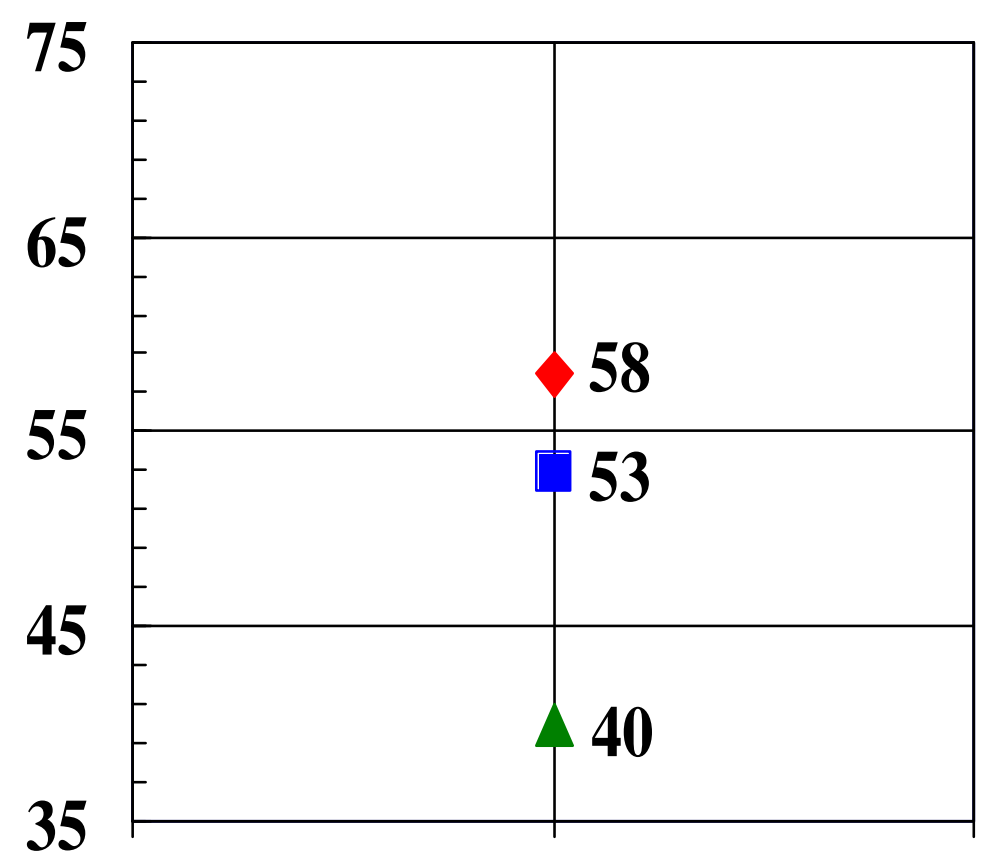

$\square$ union not employed

$\triangle$ non union

SOURCE: Tabulated from the VNS Exit Polls for 2000 (ICPSR, 3527). 